\title{
O jogo da memória como recurso pedagógico
}

João Carlos Leal Cunha*, Edmilson de Souza**

\section{Resumo}

Há algumas décadas a sociedade passa por profunda transformação cultural pautada na informática. O uso intenso de tecnologia está presente em produtos, bens e serviços, sejam eles para a mobilidade urbana, produção de alimentos, controle sanitário, produção de medicamentos, ou uso pessoal como os computadores e os celulares, cada vez mais presentes na vida dos jovens. Essa mudança cultural oferece oportunidades para o aprendizado da Matemática no âmbito escolar. O jogo, e, portanto, o brincar, é um importante recurso para potencializar o aprendizado dos estudantes no Ensino Fundamental. O presente trabalho investigou a elaboração de versões online e física do Jogo da Memória e seu uso como recurso pedagógico para auxiliar a aprendizagem de conceitos de matemática utilizando a troca simbólica entre algarismos indo-arábicos e egípcios. A pesquisa foi realizada com estudantes de duas Escolas Estaduais de Campo Grande-MS. Os resultados apontam que a complexidade gradativa dos caracteres e a exigência de realização de operações matemáticas podem alterar a tipologia da resposta dos estudantes, por outro lado, diferentes atividades, independente do uso ou não da informática, potencializam a aprendizagem dos conceitos matemáticos e a assimilação das trocas simbólicas.

Palavras-chave: Jogo da Memória. Informática na Escola. Aprendizagem de Matemática. Algarismos Egípcios.

Escola Estadual Maestro Frederico Liebermann. Doutorando em Educação atemática, Pontifícia Universidade Católica de São Paulo (PUCSP), Brasil. E-mail: jcleal02@yahoo.com.br

** Universidade Estadual de Mato Grosso do Sul (UEMS). Programa de Mestrado Profissional em Educação Científica e Matemática (PROFECM). Centro de Estudos em Recursos Naturais (CERNA). Brasil. E-mail: edmilson@uems.br 


\section{Introdução}

Atualmente, a sociedade está imersa em uma transformação cultural que valoriza o uso intenso de tecnologia através de produtos, bens e serviços, sejam eles para a mobilidade urbana, produção de alimentos, controle sanitário, produção de medicamentos, ou uso pessoal como os computadores e os celulares, cada vez mais presentes na vida dos jovens.

Essa mudança cultural também está presente na escola. Não raro, organizações escolares estabelecem regras que limitam o uso e acesso a telefones celulares, tablets e mesmo computadores portáteis. Por outro lado, também, têm ocorrido significativos esforços governamentais, por organizações escolares e professores para, gradativamente, os espaços de aprendizagem de educação formal aproveitar o potencial oferecido pelas tecnologias disponíveis. As discussões favoráveis ou contrárias parecem ser o indício de que relevantes mudanças no processo ensino-aprendizagem estão em curso na Escola devido à tecnologia. (ZUIN \& ZUIN, 2018; REINALDO et. al., 2016; NAGUMO \& TELES, 2016; SILVA, CORREIA \& LIMA, 2010)

Um ramo prestigiado pelos jovens em idade escolar, marcado pelo intenso uso tecnológico, é o entretenimento, especialmente os jogos. Os atuais telefones celulares, tablets e notebooks, permitem que estudantes, dentro do espaço escolar (ex. durante seu intervalo), se conectem em rede, com jogadores em diferentes partes do mundo. E, dessa maneira, por iniciativa própria, os estudantes ampliam seu espaço de interação e aprendizagem fora do espectro formal da escola sem nem mesmo deixá-la. (COSTA, 2018; SALGADO, 2018; SILVA, 2018; BAUMGARTEL, 2016; CRUZ, 2016; ROMANELLO, 2016; UNIGRANRIO, 2016; RIBEIRO, LEITE \& SOUSA, 2009)

A Matemática está presente, como corpo de conhecimento, em praticamente todos os processos que envolvem o desenvolvimento de produtos, bens e serviços com caráter tecnológico, seja de maneira direta ou indireta. Entretanto, os usuários dessas tecnologias, em idade escolar, nem sempre conseguem estabelecer essa relação, e mesmo não compreendem aspectos de matemática básica apresentados na Escola Formal, como indicam avaliações de larga escala. (PIZARRO \& LOPES JUNIOR, 2017; BAUER, ALAVARSE \& OLIVEIRA, 2015; KALINKE, MOCROSKY \& ESTEPHAN, 2013) 
A aprendizagem de matemática permanece desafiante. Diante de novas tecnologias, o ensino, atividade conduzida pelo docente, se apresenta como um vasto campo de oportunidades ao considerar recursos como o jogo. O jogo, tratado como recurso pedagógico, poderá aprimorar a prática do educador em matemática ao considerar o ato de brincar como parte da estratégia em sala de aula. Essa visão sobre o ato de brincar valoriza e distingue o recurso pedagógico na medida em que ele for capaz de tomar a atenção e o interesse do estudante, mantendo-se como elemento lúdico, isto é, apresentando dimensão que remete ao prazer e a alegria do estudante de realizar as rotinas e regras do jogo, que desdobra na aprendizagem. (SOUZA, 2012)

Na Matemática observa-se uma relação de semelhança entre o jogo e a resolução de problemas, ambos se alicerçam na ação do estudante e, ao considerar a ludicidade, o jogo, também, requer o prazer proporcionado pela investigação dos seus processos que decorrem do uso da estrutura de suas regras.

O termo lúdico se origina do vocabulário latino "ludus" que significa diversão, brincadeira. Portanto, a brincadeira deve se fazer presente no jogo, pois esse aspecto desenvolverá as habilidades psicomotoras da criança, a atenção, a imaginação, a concentração e a socialização, habilidades estas essenciais no convívio social e no desenvolvimento pessoal.

Segundo Kishimoto (2007), o jogo é um suporte metodológico a todos os níveis de ensino, desde que a finalidade dele seja clara; a atividade apresente caráter desafiador e que esteja adequado ao grau de aprendizagem do estudante. A autora ressalta que as situações de ensino presentes no jogo e na resolução de problemas devem ser lúdicas e priorizar a construção de novos conhecimentos.

Scheller (2018) et. ali. investigaram os ganhos cognitivos / socioemocionais de atividades que fazem uso de jogos matemáticos fora da sala de aula, durante $o$ período do lanche. Como parte dos resultados, os autores avaliaram as diferentes dimensões envolvidas nessa vivência que teve como pressuposto "de que os espaços de aprendizagem extrapolam a sala de aula, elegeu-se como espaços de desenvolvimento da proposta no ambiente escolar: parque, gramado, corredor, varanda e refeitório; todos adaptados aos diferentes jogos e situações climáticas do período.”. Esses autores, enfatizam o potencial que há no jogo para desdobrar em aprendizagens, bem como seu débito com as emoções. 
As atividades (...) ilustram que a aprendizagem de noções matemáticas não ocorre de forma linear. Foi resultado de um processo de interação mediado por educadores que souberam utilizar jogos e brincadeira oportunamente, explorando o potencial de desenvolvimento que existia por trás deles. Também é resultado de vivências que envolveram emoções e prazer, curiosidade e interesse. (SCHELLER, 2018, p. 132)

De maneira conclusiva, os mesmos autores, sentenciam aspectos capitais da relação do jogo com a aprendizagem em matemática:

(...) as atividades promoveram a participação coletiva e individual possibilitando o desenvolvimento integral da criança em seus aspectos cognitivo, afetivo e social. Sendo assim, os jogos e as brincadeiras constituem-se em recursos facilitadores e motivadores da aprendizagem e se efetivam como oportunizadores da relação da criança entre o prazer e o conhecer.(SCHELLER, 2018, p.132)

O jogo como recurso pedagógico para o ensino da matemática, pelo exposto acima, encontra ressonância nas pesquisas acadêmicas. Mas o que dizer de seu uso entre os professores que atuam diretamente na Educação Básica?

Tenório, Rodrigues e Tenório (2015) realizaram investigação com 62 professores de matemática do estado do Rio de Janeiro, com foco nas relações entre o uso de jogos em simulações computacionais. Os autores apontam que os jogos mecânicos são mais comumente empregados no ensino de matemática do que os digitais. Várias são as razões indicadas pelos professores entrevistados para o não uso dos jogos digitais, entre elas "Frequentar o laboratório de informática para empregar tecnologias de software era incomum" (TENÓRIO, RODRIGUES e TENÓRIO, 2015, p.108). Nesse mesmo estudo 55\% acusam que nunca utilizaram o laboratório de informática e outros $31 \%$ relatam que o espaço nem existe em suas escolas.

No presente trabalho de investigação avaliou-se o uso do Jogo da Memória (elaboração própria), versões física e virtual, para estudantes do Ensino Fundamental, e suas correlações com possíveis ganhos na aprendizagem de Matemática e/ou desdobramentos socioemocionais decorrentes da organização das atividades.

As atividades elaboradas foram concebidas a partir do pressuposto de que 0 cotidiano da sala de aula de Matemática, mais do que recursos tecnológicos e/ou pedagógicos, necessitam do engajamento do docente na compreensão e aprofundamento acerca do uso desses recursos virtuais ou físicos para os processos inerentes à apreensão do mundo, à aprendizagem.

Dessa maneira, o ensino, na perspectiva defendida no presente trabalho, se configura como um movimento essencialmente do protagonismo docente, cujo foco está na 
organização e compreensão dos recursos pedagógicos; elaboração e planejamento das estratégias em sala de aula; compreensão e suporte de uma matriz epistemológica, que por fim, esses e outros aspectos que auxiliam na aprendizagem do estudante.

A atividade docente, em sala de aula, compreende o exercício de mediação desse conjunto de aspectos que auxiliam a aprendizagem do estudante a fim de promover habilidades e competências que gradativamente resultem na autonomia do estudante e sua postura interferente na realidade.

\section{Metodologia}

Lembrar é fundamental. Hoje, tornou-se lugar comum considerar que a memória é parte dos recursos intelectuais que um ser humano dispõe para otimizar sua faculdade mental de aprender. O Jogo da Memória se vale dos processos de associação de imagens a partir da lembrança das mesmas, em instantes sucessivos e de curto prazo pelos estudantes.

Dessa maneira, a pesquisa é norteada por uma pergunta inicial:

O Jogo da Memória com uso de imagens (algarismos egípcios/indo-arábicos) pode ser considerado um recurso pedagógico que auxilia na aprendizagem de matemática?

Para responder à pergunta, um conjunto de atividades foram elaboradas pelos autores do presente trabalho com a finalidade de coletar dados com seu público alvo, estudantes do Ensino Fundamental. A partir dos dados coletados e da definição de uma técnica específica para análise e interpretação, foi possível realizar inferências sobre as respostas que os próprios estudantes indicam acerca de suas experiências com os diferentes momentos estabelecidos para o uso de recursos físicos e virtuais, montados sobre a ideia central do uso da memória, isto é, o Jogo da Memória.

As atividades foram divididas em três etapas:

a) Jogo da Memória: Virtual e Físico;

b) Percepção do estudante sobre os Recursos Pedagógicos e a Atividade de Matemática;

c) Jogo da Memória: Cartas Virtuais, Cruzadinha e Quiz.

A pesquisa foi desenvolvida em duas escolas estaduais, com estudantes do $6^{\circ}$ ano do Ensino Fundamental, localizadas no município de Campo Grande-MS. As escolas estão designadas pelas letras $\mathrm{A} \mathrm{e} \mathrm{B}$, sendo que a A ofereceu o ensino regular no ano de 2017 e assinalou 5,8 no IDEB (Índice de Desenvolvimento da Educação 
Básica); e a Escola B ofereceu o ensino integral, no ano de 2017 e alcançou 4,2 no IDEB. Os participantes da pesquisa estão em uma faixa etária média de dez anos.

O trabalho de investigação se pautou em atividades programadas e aplicadas para 9 (nove) encontros com os estudantes de ambas escolas. Os encontros foram realizados em dois momentos: a) em fevereiro de 2018, sendo 6 (seis) encontros, e, b) em junho de 2018, com 3 (três) encontros.

No primeiro momento, em fevereiro, as atividades abrangeram as etapas "a" e "b", isto é, o "Jogo da Memória: Virtual e Físico", e a "Percepção do estudante sobre os Recursos Pedagógicos e a Atividade de Matemática", respectivamente. O segundo momento, em junho, as atividades designadas por "Jogo da Memória: Cartas Virtuais, Palavra-chave e Quiz", etapa "c", foram organizadas mediante o planejamento de uma sequência didática, que aprofundou os estudos em aula sobre a correspondência entre os caracteres indo-arábicos e egípcios, bem como operações matemáticas que exploram quantidades maiores de algarismos.

A pesquisa contou com a participação de trinta e um estudantes e o tempo utilizado nas escolas foi adequado dentro da realidade de cada instituição. Ambas as turmas acolheram a pesquisa com interesse.

A presente pesquisa contou com o apoio da direção das referidas escolas através de autorização formal. As atividades desenvolvidas pelos estudantes foram registradas em fotos, cujas autorizações de direito de imagem, também, foram previamente assinadas pelos pais e responsáveis no ato da matrícula, de acordo com a normatização da Secretaria de Estado de Educação. As escolas foram escolhidas por apresentarem realidades diferentes, uma em tempo integral e outra não, porém esse aspecto não faz parte do escopo de análise do presente trabalho.

Com a finalidade de esmiuçar o roteiro metodológico da pesquisa, a seguir, são apresentados: o método de Análise de Conteúdo, utilizado para compreender as mensagens que as respostas dos estudantes, nas atividades propostas, comunicam acerca do uso do jogo da memória; e, a descrição de cada uma das atividades propostas, sua mecânica, bem como a forma dos dados gerados.

\section{Análise de Conteúdos}

Os dados coletados foram organizados e analisados segundo o método conhecido como Análise de Conteúdo (AC). A abordagem utilizada foi da pesquisadora francesa Laurence Bardin que descreve o alcance de aplicabilidade de seu trabalho como: 
[...] apercebemo-nos de que o campo de aplicação é extremamente vasto. Em última análise, qualquer comunicação, isto é, qualquer transporte de significações de um emissor para um receptor controlado ou não por este, deveria poder ser escrito, decifrado pelas técnicas de análise de conteúdo.(BARDIN, 2011, p.32)

De maneira mais específica, de acordo com Bardin $(2011$, p.42) a análise de conteúdo pode ser definida como:

[...] um conjunto de técnicas de análise das comunicações visando a obter, por procedimentos sistemáticos e objetivos de descrição do conteúdo das mensagens, indicadores (quantitativos ou não) que permitam a inferência de conhecimentos relativos às condições de produção/recepção (variáveis inferidas) destas mensagens.

Diante do exposto, a escolha do método foi devido a natureza dos dados obtidos se configurarem, em sua maior parte, em registros tácitos e frequentes de palavras e símbolos, que à luz do tratamento proposto por Bardin podem ser categorizados de maneira que as "mensagens" (ou os significados) permitam que os registros dos estudantes (os dados) "falem" e, inferências possam ser realizadas a respeito dessas mensagens.

Considerando as características dos dados coletados e o conjunto de técnicas da $\mathrm{AC}$, optou-se pelo uso da técnica de análise categorial, que "cronologicamente é a mais antiga; na prática é a mais utilizada. Funciona por operações de desmembramento do texto em unidades, em categorias segundo agrupamentos analógicos”. (BARDIN, 2016, p.201)

Uma vez definida a técnica a ser utilizada, de maneira geral, a aplicação é estabelecida, de acordo com Bardin (2011, p.95), através de um processo que compreende três fases: 1) pré-análise; 2) exploração do material; 3) tratamento dos resultados.

A pré-análise compreende a fase de organização dos dados. Esse momento corresponde a um "período de intuições, mas, tem por objetivo tornar operacionais e sistematizar as ideias iniciais, de maneira a conduzir a um esquema preciso do desenvolvimento das operações sucessivas, num plano de análise.”. De maneira gradativa, esse contato inicial, de caráter mais livre, com o material coletado permitiu aos investigadores delimitar o alcance tanto dos próprios dados, quanto dos desdobramentos possíveis a partir deles. (BARDIN, 2011, p.95)

Como o trabalho foi realizado em dois diferentes períodos cronológicos, fevereiro e junho, os dados produzidos pelos estudantes no primeiro momento (fevereiro) permitiu alcançar, dentro da fase de pré-análise, os dois principais objetivos que a técnica defende: 


\begin{abstract}
a superação da incerteza: o que eu julgo ver na mensagem estará lá efetivamente contido, podendo esta visão muito pessoal ser partilhada por outros? Por outras palavras, será a minha leitura válida e generalizável?

o enriquecimento da leitura: se um olhar imediato, espontâneo, é já fecundo, não poderá uma leitura atenta aumentar a produtividade e a pertinência? Pela descoberta de conteúdos e de estruturas que confirmam (ou infirmam) o que se procura demonstrar a propósito das mensagens, ou pelo esclarecimento de elementos de significações suscetíveis de conduzir a uma descrição de mecanismos de que $a$ priori não possuíamos a compreensão. (BARDIN, 2016, p.34)
\end{abstract}

A percepção desses objetivos, através dos dados, permitiu realizar modificações no perfil das atividades a serem realizadas no segundo momento, em junho.

No que tange à superação da incerteza, a técnica deveria permitir que os dados "falassem" acerca da hipótese inicial, interna à experiência dos proponentes da pesquisa. Essa hipótese inicial era de que os estudantes deveriam responder melhor à identificação e à correspondência simbólica entre os caracteres indo-arábicos e egípcios, do que à identificação e à correspondência simbólica através de operações matemáticas.

Diante dessa hipótese, foram estabelecidas apenas as chamadas unidades de registro, como parte da segunda fase da técnica de análise de conteúdo, a exploração do material, que se baseiam no conjunto de dados das duas primeiras etapas de atividades: a) Jogo da Memória Virtual e Físico, e b) Percepção do estudante sobre os Recursos Pedagógicos e a Atividade de Matemática.

De acordo com Bardin (2016, p.133) "tratar o material é codificá-lo”. Essa codificação corresponde ao processo em que os "dados brutos são transformados sistematicamente e agregados em unidades, as quais permitem uma descrição exata das características pertinentes do conteúdo", e, de acordo com a técnica a organização desse processo de codificação implica na escolha de: 1) Unidades: que representam os recortes de dentro do conteúdo, e, carregam a significação codificada; 2) Regras de Contagem: que permitem avaliar a frequência dessas unidades; 3) Categorias: que classificam e agregam perfis decorrentes das unidades e contagem.

Como parte da fase de exploração do material, dentro do primeiro momento, foram definidas um conjunto de unidades de registro referentes às etapas "a" e "b" de atividades propostas, conforme ilustra o quadro 01. 
Quadro 1: Unidades de Registro - Primeiro Momento (Fevereiro)

\begin{tabular}{|c|c|}
\hline Atividades & Unidade de Registro \\
\hline 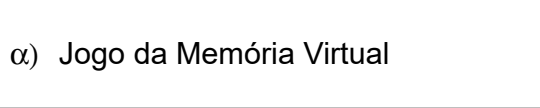 & $\begin{array}{l}\text { Número Mínimo de Jogadas } \\
\text { Número Máximo de Jogadas }\end{array}$ \\
\hline $\begin{array}{l}\text { ß) Percepção do Estudante sobre os } \\
\text { Recursos Pedagógicos e a Ativida- } \\
\text { de de Matemática }\end{array}$ & $\begin{array}{l}\text { Familiaridade com a Informática } \\
\text { Familiaridade com o Jogo } \\
\text { as palavras: Difícil, Divertido, Interessante, Legal e Ruim }\end{array}$ \\
\hline
\end{tabular}

$\mathrm{Na}$ etapa "c" das atividades do jogo da memória (Cruzadinha, Quiz e Cartas Virtuais), dentro do segundo momento (junho), considerando a fase de exploração do material, um conjunto mais simples e tácito de unidades de registro foi proposto para avaliar a resposta dos estudantes. $\mathrm{O}$ quadro 02 ilustra as unidades de registro definidas.

Quadro 2: Unidades de Registro - Segundo Momento (Junho)

\begin{tabular}{|l|l|}
\hline \multicolumn{1}{|c|}{ Atividade } & \multicolumn{1}{c|}{ Unidade de Registro } \\
\hline Cruzadinha e Quiz & $\begin{array}{l}\text { Acerto } \\
\text { Erro }\end{array}$ \\
\hline Cartas Virtuais & $\begin{array}{l}\text { Número Mínimo de Jogadas } \\
\text { Número Máximo de Jogadas } \\
\text { as palavras: Bom, Confuso, Diferente, Difícil, Divertido, Fácil, Interessante, } \\
\text { Legal, Muito Bom, Muito Irado e Ótimo }\end{array}$ \\
\hline
\end{tabular}

Com a complementação dos dados da exploração do material do segundo momento (Jogo da Memória: Cartas Virtuais, Palavra-chave e Quiz), em junho, foi possível o estabelecimento de categorias para agrupar as unidades de registro. Duas categorias foram definidas: a) Desempenho e, b) Interesse.

A categoria "Desempenho" procura agregar as unidades de registro de ambos os períodos cronológicos de atividades, de acordo com sua base comum de significação (Número Máximo de Jogadas, Número Mínimo de Jogadas, Acerto e Erro), com a finalidade de compreender se efetivamente o uso das trocas simbólicas e da presença de operações matemáticas foram apreendidas pelos estudantes.

A categoria "Interesse" foi cunhada a partir da análise das unidades de registro na forma de palavras, que foram propostas em ambos os momentos da pesquisa, fevereiro e junho. É relevante destacar que no primeiro momento as unidades de 
registro eram fixas, restando ao estudante a escolha entre as unidades de registro definidas. Enquanto no segundo momento, os próprios estudantes escolhiam, livremente, que palavras (unidade de registro) mais bem representassem suas impressões sobre a atividade. Essa categoria reúne a significação codificada que procura responder à dimensão do lúdico, isto é, a avaliação que os estudantes fazem sobre se as atividades são prazerosas/agradáveis ou não.

A terceira fase da técnica da análise de conteúdo, o tratamento dos resultados, não foi linear. A fase foi caracterizada por idas e vindas, e as intuições iniciais (previstas na técnica), bem como a hipótese inicial, que auxiliaram na estabilização da compreensão acerca de quais categorias mais bem fariam o papel de comunicar a "mensagem do jogo da memória", em vários momentos exigiu uma releitura dos dados iniciais, e de considerar um exame acerca do significado da frequência das unidades de registro. Esse processo cumpriu o segundo objetivo da técnica que foi o "enriquecimento da leitura" que terminou por permitir as inferências, como parte necessária da fase de interpretação dos resultados.

\section{○ Jogo da Memória Virtual e Físico}

O Jogo da Memória Virtual compreendeu a elaboração de cartas com símbolos que ilustram caracteres egípcios e indo-arábicos, que expressam quantidades e operações matemáticas. A elaboração das cartas e do jogo foi de autoria própria do investigador (autor 1 do presente trabalho) e professor de Matemática (que atua há 30 anos na Educação Básica). Utilizou-se para confecção das cartas e desenvolvimento do jogo o Sistema Educacional Online (SEDUC ONLINE) que é uma rede social de conhecimento com finalidade de criar jogos online, de caráter gratuito, desafios e atividades educativas diversas. O uso de programas desenvolvidos no SEDUC exige inserir os estudantes em atividades de informática. No caso do presente trabalho isso significa inseri-los em ambiente específico da escola, na chamada Sala de Tecnologia.

O jogo apresentou duas fases. Na primeira fase, os jogadores deveriam, a partir da lembrança dos caracteres indo-arábicos e egípcios, bem como o conhecimento acerca das correspondências quantitativas, montar pares de cartas devido sua igualdade matemática. Na segunda fase, além da habilidade exigida na primeira fase, os jogadores deveriam montar os pares de cartas a partir da solução de operações matemáticas, que, intercambiam o uso dos caracteres indo-arábicos e egípcios. 
O parâmetro objetivo utilizado foi o número de jogadas que eram necessárias para os estudantes concluírem o jogo, isto é, desvendarem todas as correspondências entre as cartas. O próprio sistema do SEDUC contabilizava as jogadas dos estudantes. Em ambas as fases foi estabelecido como regra: que após o primeiro jogador concluir a fase, todos os demais teriam 10 minutos adicionais para a integralização do jogo. Para efeito de análise posterior, foi adotado como referência o valor de 30 jogadas para concluir o jogo. Esse número foi obtido considerando o tempo disponível de aula, para efetivamente os estudantes jogarem, Foi necessário desconsiderar o tempo de intervenções do professor com as explicações da atividade e uma margem de segurança para não extrapolar o tempo da aula.

O jogo da memória, também, teve sua versão fora da sala de tecnologia (Jogo da Memória Físico), distante dos computadores e do ambiente com apelo tecnológico. Essa atividade organizada em sala de aula fez uso de materiais de baixo custo e fácil acesso aos estudantes, que valorizam a construção através da manipulação e ação colaborativa. Essa etapa da investigação procurou valorizar o aspecto presente nos discursos escolares tanto entre professores, quanto estudantes, qual seja, de que é necessário "aprender na prática", com a "mão na massa".

O jogo da memória torna-se nesse sentido um recurso pedagógico físico, familiar ao estudante, porque sendo ele o autor, o objeto de conhecimento (Matemática) através de suas próprias mãos ganha uma dimensão concreta, palpável, tangível, lúdica ao desenrolar do processo de familiarização com as características menos tangíveis inicialmente, tal como a troca simbólica e as operações matemáticas utilizando as variações simbólicas. $\mathrm{Na}$ atividade na sala de aula o objetivo foi construir as cartas e jogar livremente, com a hipótese de que esse momento adicional, em um tempo futuro, resultaria em melhor desempenho em nova etapa de atividades.

\section{Percepção do estudante sobre os Recursos Pedagógicos}

A segunda etapa de atividades foi elaborada para cumprir dois objetivos: (1) Reforçar a vivência dos estudantes com os elementos do jogo da memória e, ao mesmo tempo (2) avaliar a percepção dos estudantes sobre a primeira etapa (Jogo da Memória Virtual e Físico). As atividades abrangem três diferentes formas (instrumentos avaliativos) de obter dados sobre o olhar dos estudantes em seu contato 
com o jogo da memória, sendo elas: a) Questionário; b) Palavra Chave e, c) Painel Palavra e Símbolo.

A concepção desses instrumentos avaliativos foi montada sobre três critérios:

1) ser parte do processo de reflexão dos estudantes sobre as correspondências simbólicas e quantitativas dos caracteres indo-arábicos e egípcios;

2) avaliar o uso dos recursos pedagógicos;

3) atender à realidade do tempo e da dinâmica da organização da própria escola e da sala de aula real.

O instrumento designado por "Questionário” abrange 5 (cinco) perguntas, sendo duas delas destinadas a compreender a percepção que os estudantes possuem a respeito do ambiente da sala de tecnologia, as outras três abordando o jogo da memória. As questões propostas foram:

01 - Você já usou anteriormente a sala de tecnologia?

02 - Você gostou das aulas de Matemática na sala de tecnologia?

03 - Você achou o jogo da memória fácil?

04 - Você acha que o jogo da memória ajudou em sua concentração e na memória?

05 - O jogo da memória ajudou a melhorar o relacionamento com os colegas da sala?

O instrumento "Palavra-chave" foi utilizado para investigar a resposta dos estudantes às unidades de registro (palavras) pré-definidas, com intuito de ter um indicador, embora rudimentar, sobre as percepções subjetivas dos estudantes. Cada estudante deveria escolher uma única palavra, e, o critério de escolha foi definido como: A palavra que mais bem representasse sua avaliação sobre as atividades realizadas. As palavras listadas foram: Interessante, Legal, Divertido, Difícil e Ruim.

O terceiro instrumento, "Painel Palavra e Símbolo", estimulou os estudantes a brincarem na lousa com a montagem de um painel a partir de palavras e os caracteres indo-arábicos e egípcios. A atividade exigiu planejamento e conhecimento do conteúdo a ser elaborado e apresentado durante as aulas a toda a turma. Sua principal função era elevar a vivência dos estudantes com o tema, sem a preocupação em produzir um registro formal a ser mensurado pela pesquisa a exemplo do Jogo da Memória Físico, na primeira fase do trabalho.

A atividade que ocorreu em sala de aula e as ações dos estudantes respondiam à questão proposta para o painel: “Qual é o símbolo egípcio?” 
Na tabela, que foi fixada na lousa, à frente de todos os estudantes, foram dispostos os registros que continham alguns valores numéricos indo-arábicos. Também, foram elaborados cartões dos símbolos egípcios para um sorteio. A atividade consistia em verificar se o estudante havia assimilado a correspondência entre os caracteres indo-arábicos e os egípcios. Posteriormente, de forma individual, e, mediante sorteio de um cartão, os estudantes iriam à frente participar, através da colocação justaposta dos numerais equivalentes entre os dois sistemas estudados. Os cartões foram organizados em conjuntos de quinze perguntas.

\section{Jogo da Memória: Cartas Virtuais, Cruzadinha e Quiz}

A terceira etapa do trabalho reuniu três atividades. O jogo designado "Cartas Virtuais", foi a primeira atividade, que seguiu o mesmo modelo do Jogo da Memória Virtual aplicado no primeiro momento, em fevereiro. A diferença entre os dois é que a segunda fase do jogo "Cartas Virtuais" apresenta maior complexidade das informações presentes nas cartas. De maneira específica, há maior presença de caracteres indo-arábicos e egípcios, na forma de operações matemáticas, que intercambiam as representações simbólicas.

A Cruzadinha e o Quiz consistem em responder a questionamentos que abrangem desde a identificação de caracteres à quantidades e operações matemáticas. As respostas de ambos geram dados que se complementam, verificando possíveis contradições na identificação entre símbolos e quantidades. Entretanto, há diferenças na forma de obter a resposta do estudante. Na Cruzadinha, as respostas exigem, do estudante, correlacionar (cruzar) os questionamentos, isto é, identificar de fato as equivalências entre a quantidade e a representação simbólica. No Quiz, há mais de uma alternativa para o estudante avaliar.

\section{Resultados e Discussão}

Os estudantes das escolas A e B, ao participarem do Jogo da Memória Virtual na plataforma SEDUC ONLINE em sua primeira fase, foram incentivados a associarem as cartas de símbolos egípcios aos valores numéricos indo-arábicos. $\mathrm{Na}$ segunda fase do jogo, o foco dos estudantes era a formação de pares de cartas com operações matemáticas considerando as trocas simbólicas entre algarismos indo-arábicos e 
egípcios. Os dados obtidos foram organizados considerando a correspondência entre o número de jogadas necessárias para a integralização de cada uma das duas fases do jogo e o quantitativo de estudantes em cada grupo de jogadas. A avaliação foi feita ao analisar o número de jogadas mínimas e máximas. Foi adotado o valor de referência de 30 jogadas. Abaixo desse quantitativo os estudantes estariam dentro do tempo razoável para a conclusão do jogo.

$\mathrm{Na}$ Escola A, participaram quinze estudantes na atividade do Jogo da Memória Virtual. Nessa escola, durante a primeira fase, o menor número de jogadas foi de dezoito, enquanto o maior quantitativo de jogadas para integralização foi de quarenta e quatro.

Na segunda fase, cujas cartas traziam operações matemáticas, houve sensível variação no número de jogadas necessárias para a integralização do jogo. O quantitativo de jogadas se deslocou positivamente, oscilando entre vinte e seis (mínimo) e cinquenta e duas (máximo) jogadas. As figuras 01 (primeira fase) e 02 (segunda fase) ilustram as relações entre o número de jogadas e o número de estudantes da Escola A. As bolhas em vermelho representam agrupamentos de estudantes que conseguiram concluir o jogo com menor número de jogadas (abaixo de 30). As bolhas em azul correspondem aos agrupamentos de estudantes com necessidade de maior número de jogadas e tempo adicional para integralizar a fase. A dimensão da bolha ilustra o tamanho do agrupamento de estudantes.

Figura 1: Primeira Fase do Jogo da Memória Virtual - Escola A

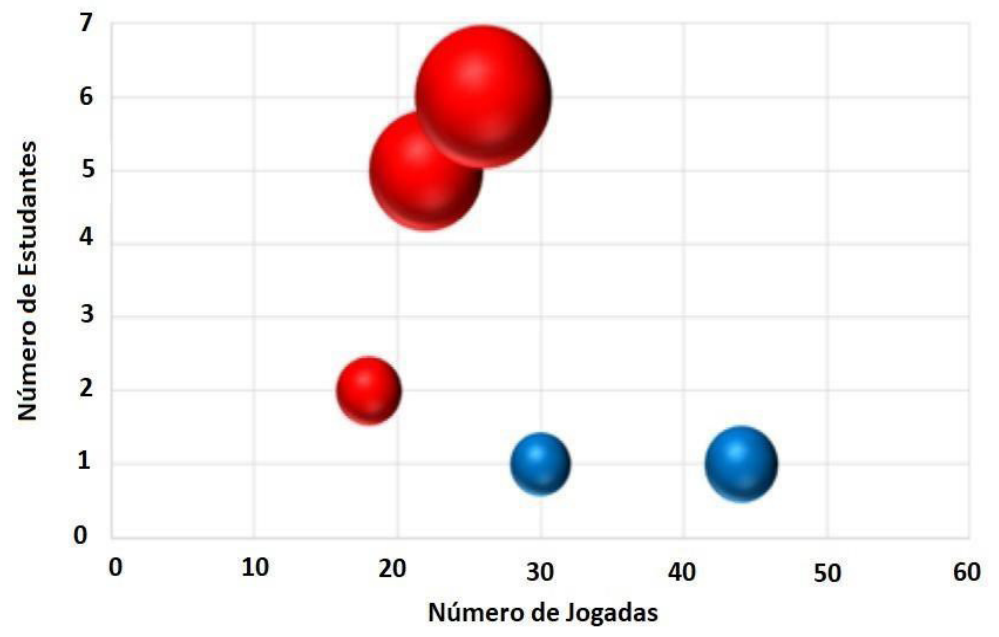


Figura 2: Segunda Fase do Jogo da Memória Virtual - Escola A

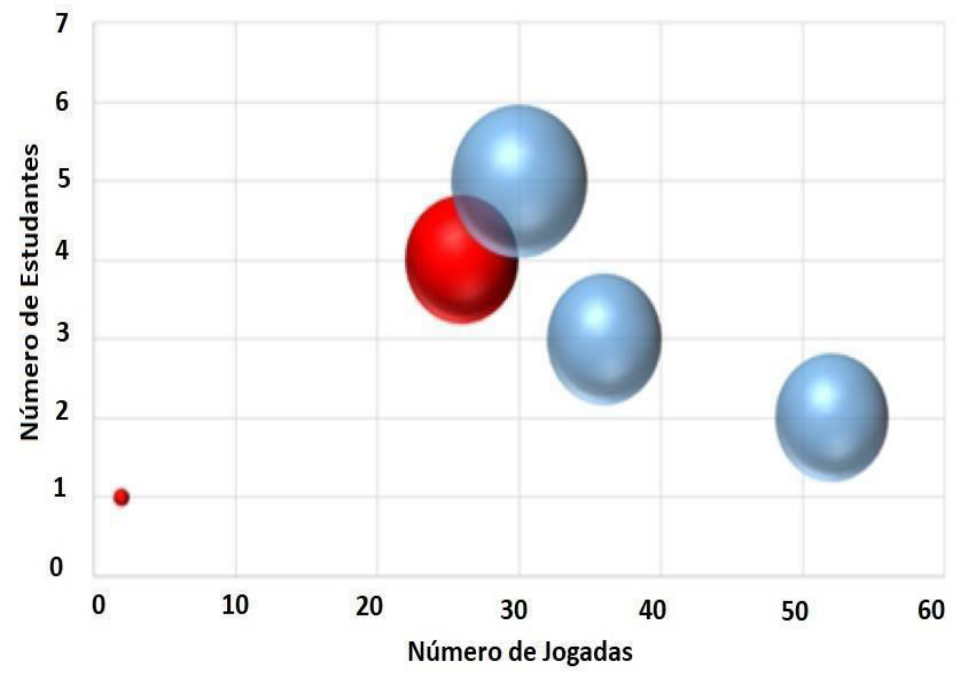

É possível, comparativamente, verificar que na figura 02 as bolhas azuis são mais pronunciadas do que na figura 01, o que implica que um contingente maior de estudantes necessitou de tempo adicional, e, de maior número de jogadas, para a integralização do jogo.

Na primeira fase, figura 01, as bolhas vermelhas são expressivas, representando $87 \%$ dos estudantes, que concluíram o jogo com número satisfatório de jogadas, abaixo de 30. Por outro lado, na segunda fase, que envolvia o reconhecimento e a realização de operações matemáticas, o contingente de estudantes que necessitou de maior tempo e número de jogadas para concluir o jogo (bolhas azuis) elevou-se de $13 \%$ (primeira fase) para $67 \%$ na segunda fase.

Na Escola B participaram da atividade dezesseis estudantes. Durante a primeira fase foram necessárias o mínimo de vinte jogadas e o máximo de cinquenta jogadas, para diferentes agrupamentos de estudantes concluírem a fase. Na segunda fase, o menor número de jogadas foi de vinte e o maior número foi de quarenta para concluir a fase. As figuras 03 e 04 ilustram os resultados, respectivamente, nas primeira e segunda fases do Jogo da Memória Virtual com os estudantes da Escola B. 
Figura 3: Primeira Fase do Jogo da Memória Virtual - Escola B

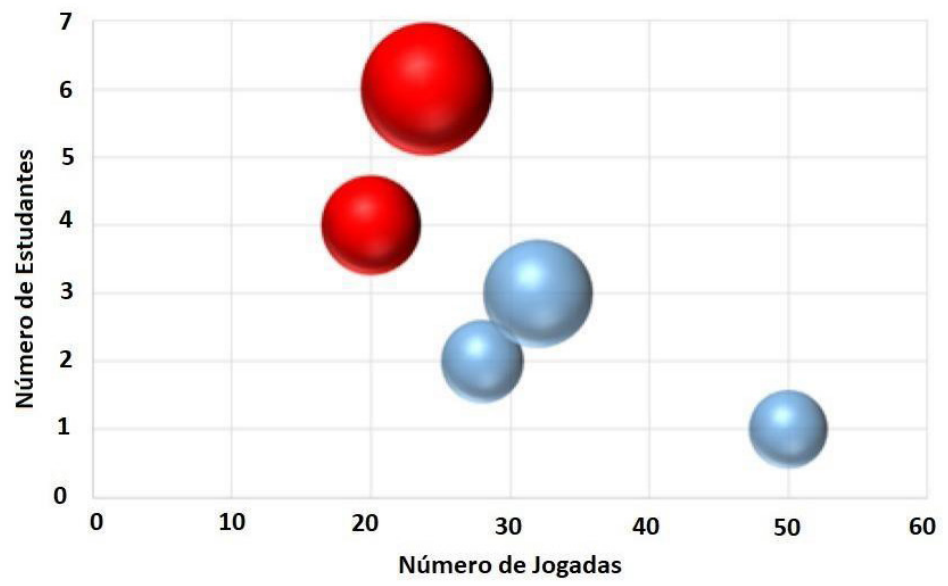

As bolhas em vermelho, figura 03, ilustram os grupos de estudantes que, com um número menor de jogadas, conseguiram finalizar o processo completo de identificação e correspondência dos símbolos indo-arábicos e egípcios, cerca de $63 \%$ dos estudantes. Dois estudantes que conseguiram concluir o jogo abaixo de 30 jogadas foram representados em azul devido terem usado tempo adicional. Entretanto, como ficaram dentro da meta de jogadas foram contabilizados junto ao primeiro grupo. Dessa maneira, cerca de $25 \%$ dos estudantes utilizaram de maior tempo e maior número de jogadas, que oscilaram entre 33 e 50 jogadas para conclusão.

Figura 4: Segunda Fase do Jogo da Memória Virtual - Escola B

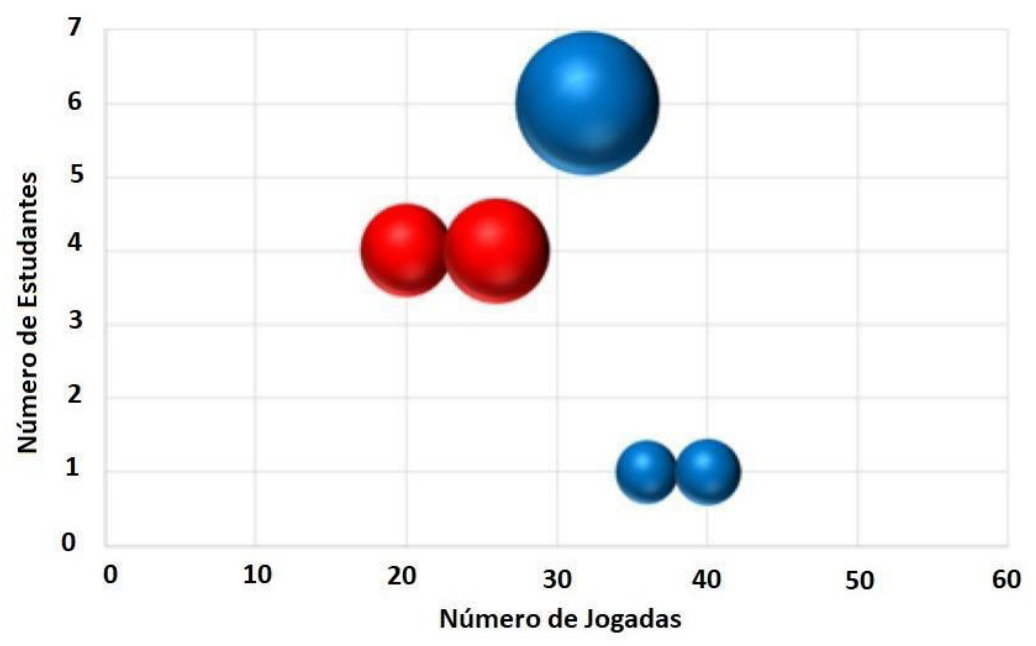


A figura 04 ilustra o resultado referente à segunda fase, em que as bolhas vermelhas diminuem sua expressão, comparativamente à figura 03 . $\mathrm{O}$ número de estudantes que atingiram a meta, de concluir o jogo abaixo de 30 jogadas, foi reduzido em $75 \%$ em relação à primeira fase. Por outro lado, o percentual de estudantes que demandam mais de 30 jogadas e tempo adicional, para concluir o jogo por completo, salta de $25 \%$ para $50 \%$, indicando que encontram maior dificuldade para lidar com as cartas que traziam em seu corpo operações matemáticas.

Os resultados anteriores foram analisados de acordo com a definição de duas unidades de registro sendo elas: 1) número mínimo de jogadas e 2) número máximo de jogadas. A partir dessas duas unidades de registro serão agrupados todos os dados apresentados anteriormente, como maneira de compreender suas relações quantitativas e de frequência.

A tabela 01 reúne os dados das unidades de registro em valores absolutos que abrangem os dados das fronteiras superior e inferior do jogo, isto é, os agrupamentos com as menores e maiores números de jogadas. Também, estão reunidas as unidades de registro com valores percentuais que identificam a frequência da obtenção da meta de jogadas em relação ao número de jogadas de referência (mínimo: menor do que 30 jogadas / máximo: igual ou maior a 30 jogadas).

Tabela 1: Unidades de Registro - Consolidação de Dados das Escolas A e B

\begin{tabular}{c|c|c|c|c|c}
\cline { 3 - 6 } \multicolumn{2}{c|}{} & \multicolumn{4}{c}{ Unidades de Registro } \\
\cline { 3 - 6 } \multicolumn{2}{c|}{} & \multicolumn{2}{c}{$\begin{array}{c}\text { Número de Jogadas } \\
\text { (valores absolutos) }\end{array}$} & \multicolumn{2}{c}{$\begin{array}{c}\text { Número de Jogadas } \\
\text { (valores percentuais) }\end{array}$} \\
\hline \multirow{2}{*}{ Escola } & Fases & Mínimo & Máximo & Mínimo (\%) & Máximo (\%) \\
\hline \multirow{2}{*}{ A } & 1 & 18 & 44 & 87 & 13 \\
\cline { 2 - 6 } & 2 & 26 & 52 & 73 & 67 \\
\hline \multirow{2}{*}{ B } & 1 & 20 & 50 & 50 & 50 \\
\cline { 2 - 6 } & 2 & 20 & 40 & & 25 \\
\hline
\end{tabular}

Ao analisar, na tabela 01 , os dados das escolas $\mathrm{A}$ e $\mathrm{B}$, com relação às unidades de registro com valores absolutos, observa-se que, independente da fase, o número máximo de jogadas é equivalente ao dobro do número mínimo de jogadas. Adicionalmente, verifica-se que a razão entre número máximo de jogadas e número mínimo de jogadas são semelhantes em função da fase, isto é, para a fase 1 ambas as escolas apresentaram razão próxima $(2,4)$ ou igual a 2,5 , enquanto na fase 2 a razão foi exatamente igual a 2,0 para ambas. A fase 1 apresenta um leve incremento na amplitude em relação à fase 2 em ambas as escolas. 
Com relação ao conjunto de dados das unidades de registro com valores percentuais é verificado que o comportamento do número mínimo de jogadas (e também do número máximo de jogadas) entre as fases 1 e 2, em ambas as escolas, são semelhantes. O número mínimo de jogadas sofre redução percentual na fase 2 , enquanto, de maneira inversa, o número máximo de jogadas na fase 2 se eleva. Destaca-se que na fase 1, em ambas as escolas, a amplitude é maior em relação à fase 2.

É possível inferir acerca dos resultados acima que, de maneira geral, os estudantes encontraram maiores dificuldades quando o jogo elevou o grau de exigência, incluindo a resolução de operações matemáticas, que além da exigência de identificar e reconhecer a correspondência entre os símbolos indo-arábicos e egípcios, também, exige o uso do raciocínio lógico e matemático para efetuar as operações, isto é, há a ampliação do número de caracteres e exigência de realização efetiva de cálculo nas cartas da segunda fase. Por outro lado, a redução na amplitude na fase 2, especialmente na escola $\mathrm{B}$, pode indicar ganho na familiaridade acerca dos símbolos e/ou da mecânica do próprio jogo.

O Jogo da Memória Físico, diferente de sua versão Virtual, procurou explorar o trabalho colaborativo entre os estudantes e não o monitoramento do número de jogadas. Organizados em grupos e considerando que as regras do jogo seriam as mesmas da versão Virtual, o foco passou a ser a imersão (vivência) na concepção do jogo através da confecção das cartas, e, posteriormente, a capacidade dos estudantes de, entre si, estabelecer a arbitragem do jogo a partir da experiência anterior.

A Base Nacional Comum Curricular (BNCC) aponta como competência específica para a aprendizagem de Matemática nas séries finais do Ensino Fundamental:

Interagir com seus pares de forma cooperativa, trabalhando coletivamente no planejamento e desenvolvimento de pesquisas para responder a questionamentos e na busca de soluções para problemas, de modo a identificar aspectos consensuais ou não na discussão de uma determinada questão, respeitando o modo de pensar dos colegas e aprendendo com eles. (BRASIL, 2018, p.267)

A competência destacada na citação acima, embora esteja colocada como específica para a Matemática, quando desenvolvida tem repercussão para todas as áreas da vida do estudante. É lugar comum o conhecimento de que a vida em sociedade pressupõe estabelecer relacionamentos com os outros. Esse relacionamento foi o pano de fundo para a proposição do Jogo da Memória Físico, uma vez que está centrado principalmente na cooperação entre os estudantes, isto é, o objetivo da atividade só 
é alcançado mediante o trabalho em conjunto. As figuras 05 e 06 ilustram o trabalho de um grupo de estudantes durante a confecção das cartas do jogo.

Figura 5: Grupo de Estudantes confeccionando cartas do Jogo Físico.

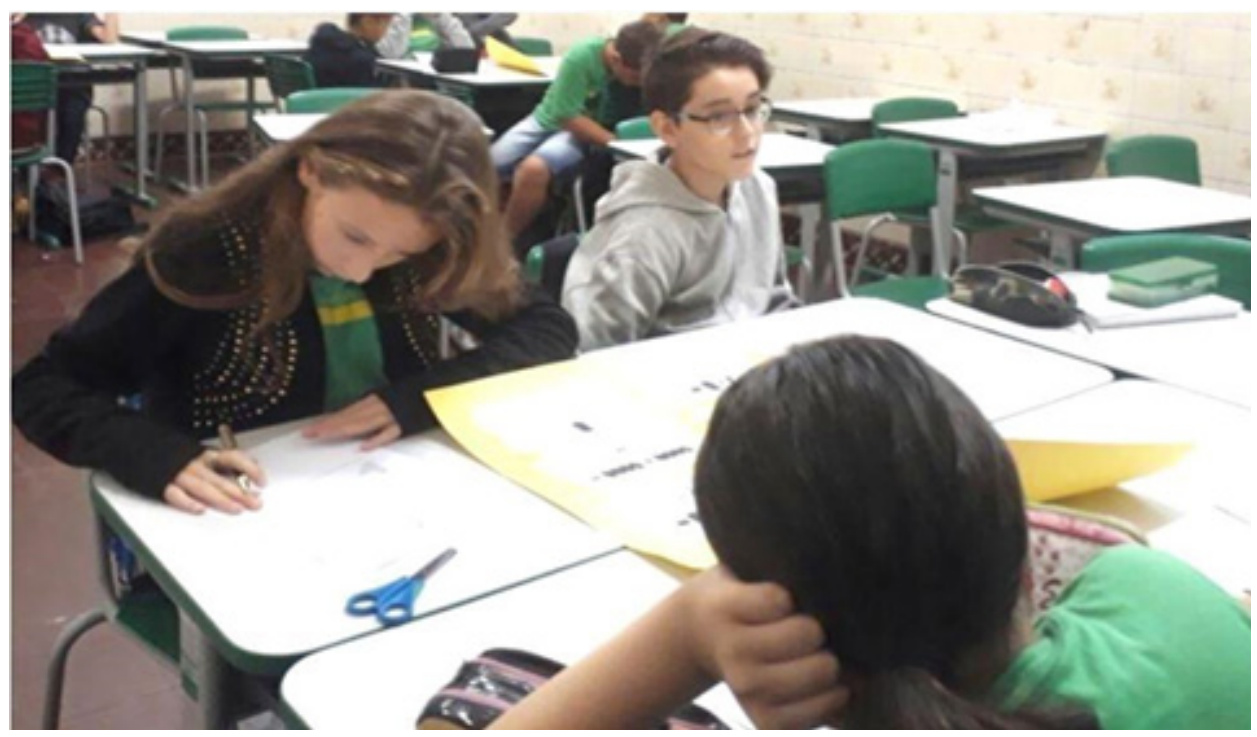

Figura 6: Grupo de Estudantes confeccionando cartas do Jogo Físico.

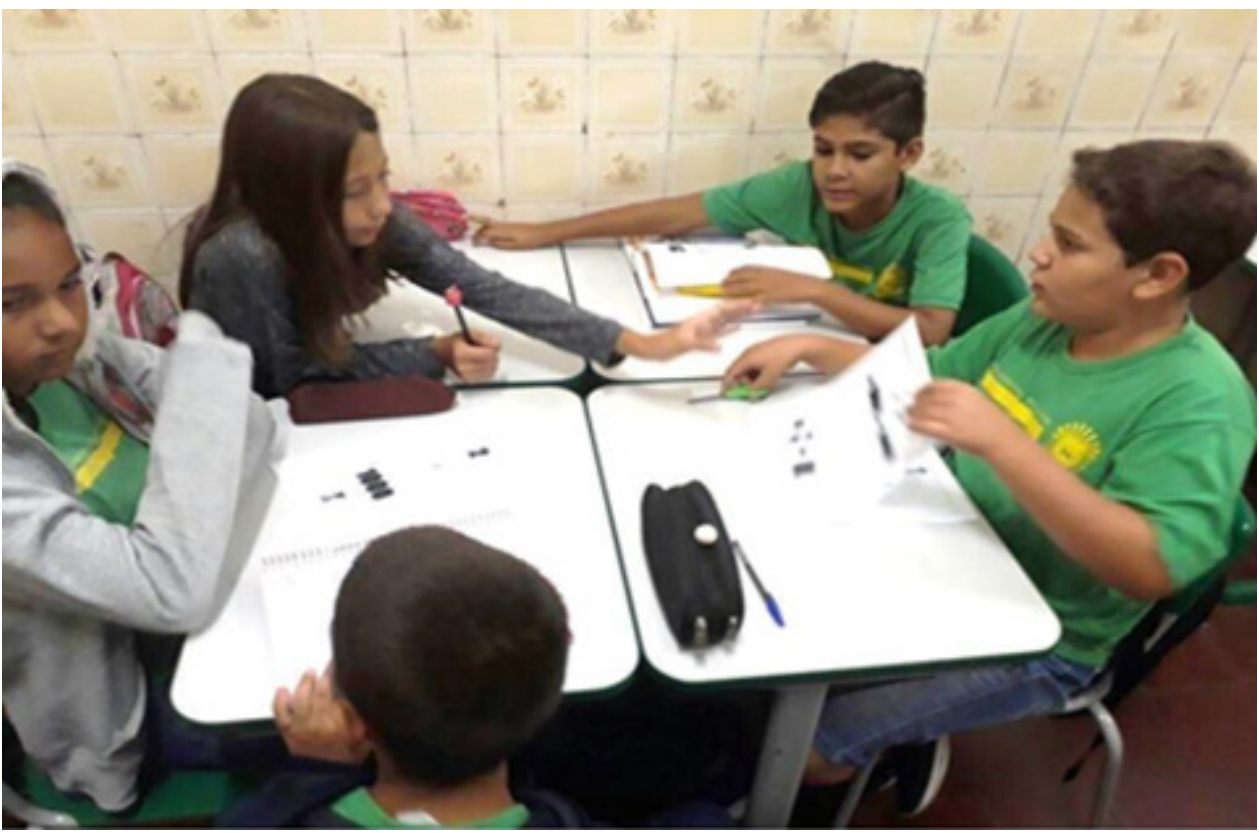


É possível observar em ambas as situações ilustradas nas figuras 05 e 06 que os estudantes estão manipulando cartões que possuem os sistemas numéricos indo-arábico e egípcio. A atividade exige a construção de consenso entre os estudantes para realizar a seleção de quais as cartas de fato irão compor o jogo de seu grupo. Esse procedimento natural acaba por ampliar as oportunidades de desenvolver a habilidade de identificar os caracteres e relacioná-los com a quantidade que representa.

Essa atividade permitiu, ao professor, realizar pequenas intervenções sobre 0 aspecto da matriz cultural da formação dos números, no caso, os ocidentais, utilizados cotidianamente pelos estudantes e os de origem egípcia. Inserir rudimentos de História da Matemática está prevista na BNCC ao lado da afirmação do uso de diferentes recursos didáticos para o ensino da matemática:

\begin{abstract}
Além dos diferentes recursos didáticos e materiais, como malhas quadriculadas, ábacos, jogos, calculadoras, planilhas eletrônicas e softwares de geometria dinâmica, é importante incluir a história da Matemática como recurso que pode despertar interesse e representar um contexto significativo para aprender e ensinar Matemática. Entretanto, esses recursos e materiais precisam estar integrados a situações que propiciem a reflexão, contribuindo para a sistematização e a formalização dos conceitos matemáticos. (BRASIL, 2018, p.298)
\end{abstract}

Pelo exposto acima, O Jogo da Memória Físico entregou como resultado o estabelecimento de momentos que propiciaram aos estudantes o fortalecimento das relações interpessoais necessárias para o trabalho em grupo, e em decorrência do processo de manipulação direta com a construção das cartas, maior familiaridade com o tema. Tornou-se notório que esse ambiente estimulou o debate, a reflexão e contribuiu para os estudantes sedimentarem maior domínio sobre a troca simbólica e as operações matemáticas envolvidas na atividade.

Os resultados das atividades que representam a etapa "Percepção do estudante sobre os Recursos Pedagógicos e a Atividade de Matemática” são apresentados na sequência. O primeiro deles, o questionário, é apresentado na tabela 02. Duas unidades de registro, familiaridade com a informática e familiaridade com o jogo, foram definidas para avaliar o conjunto de respostas. 
Tabela 2: Questionário sobre Percepção dos Estudantes

\begin{tabular}{l|r|r}
\multicolumn{1}{c|}{ Respostas em Percentagem (\%) } & \multicolumn{2}{c}{ Escolas } \\
\hline \multicolumn{1}{c|}{ Questões } & \multicolumn{1}{c|}{ A } & \multicolumn{1}{c}{ B } \\
\hline Você já usou anteriormente a Sala de Tecnologia? & 80 & 81 \\
\hline Você gostou das aulas de Matemática na sala de tecnologia? & 100 & 100 \\
\hline Você achou o jogo da memória fácil? & 100 & 88 \\
\hline Você acha que o jogo da memória ajudou em sua concentração e memória? & 100 & 88 \\
\hline O jogo da memória ajudou a melhorar o relacionamento com os colegas da sala? & 73 & 75 \\
\hline
\end{tabular}

A unidade de registro designada por familiaridade com a informática abrangeu as duas primeiras questões. A questão inicial sonda a familiaridade dos estudantes com a sala de tecnologia e por conseguinte, com seus recursos. Na questão "Você já usou anteriormente a sala de tecnologia?", as respostas foram semelhantes em ambas as escolas A e B. Cerca de $80 \%$ dos estudantes responderam positivamente, afirmando que frequentaram várias vezes o espaço da sala de tecnologia, o que implica que a maioria dos estudantes realizaram atividades com uso do computador em outras disciplinas. Embora o jogo da memória, na forma digital, tenha sido construído para ser intuitivo para o estudante, a não familiaridade com o uso do computador disponível na própria escola pode dificultar, intimidar ou mesmo oferecer desconforto para a realização adequada da atividade proposta.

A segunda questão "Você gostou das aulas de Matemática na sala de tecnologia?" remete à percepção da atividade proposta na sala de tecnologia como prazerosa (ou não). As respostas dos estudantes foram unânimes em indicar positivamente, que o jogo da memória em sua versão online foi uma atividade agradável.

A familiaridade com o jogo foi definida como outra unidade de registro para avaliar o conjunto das três últimas questões. Os estudantes, em resposta à terceira questão, avaliaram o jogo da memória como "fácil", sendo esta manifestação na escola A de $100 \%$ e na escola B de $88 \%$.

Ao verificar junto aos estudantes se os mesmos julgam que as atividades realizadas conferem algum ganho, sejam eles cognitivos (quarta questão) ou socioemocionais (quinta questão), avaliaram que a atenção e a memória (entre $88 \%$ e 100\%) são características mais pronunciados do que as relações interpessoais (73\% a 75\%). A respeito da importância de considerar a atenção e a memória como indicador de ganho cognitivo em jogos de caráter digital, a pesquisa de Silva e Scheffer (2019, 
p. 170) afirma que os mesmos "beneficiam os estudantes na aprendizagem dos conceitos básicos da Matemática e desenvolvem as funções cognitivas de atenção e memória, imprescindíveis para a disciplina".

A unidade de registro "familiaridade com a informática" formada por seus seus componentes, as duas primeiras questões da tabela 02, confirma que os estudantes tanto da escola $\mathrm{A}$, quanto da escola $\mathrm{B}$, demonstram, através de suas respostas, que conhecem o ambiente da sala de tecnologia, e possivelmente tem uso frequente de seus recursos. Porém, os estudantes avaliam melhor a atividade proposta pelo jogo da memória do que o próprio uso do ambiente onde o jogo é realizado.

As três últimas questões da tabela 02 formam o conteúdo da unidade de registro "familiaridade com o jogo". Embora com percentuais altos em todas as respostas em ambas as escolas, acima de 70\%, o aspecto do trabalho cooperativo entre os estudantes obteve avaliação negativa por cerca de 1/4 do conjunto de todos os estudantes. De maneira geral, a unidade de registro indica que os estudantes percebem "ganhos" proporcionados pelo jogo da memória, em parte porque a atividade é reconhecida como acessível e compreensível (questão 3), em parte porque o conteúdo do jogo obteve a atenção (questão 4), auxiliando no processo de memória.

O segundo instrumento de avaliação da percepção dos estudantes sobre o jogo da memória foi a escolha de uma "palavra-chave" ou uma unidade de registro. A análise dos dados indica significativas diferenças na avaliação que os estudantes de ambas as escolas fizeram sobre as atividades realizadas.

$\mathrm{Na}$ escola A se verificou o predomínio de uma palavra para representar sua percepção sobre as atividades. A palavra INTERESSANTE foi escolhida por $64 \%$ dos estudantes como principal característica das atividades realizadas. Mas o que significa classificar as atividades realizadas como "interessante" para os estudantes?

Entre as palavras selecionadas nesta escola não aparece nenhuma que indique desaprovação das atividades, porém, a divisão percentual das escolhas merece maior atenção.

Entre as palavras selecionadas pelos estudantes, uma em especial é utilizada no dia a dia por eles, LEGAL. Em geral, esse termo é utilizado indiscriminadamente por crianças e jovens, para praticamente qualquer objeto, pessoa ou circunstância, mas que, claramente, o impele a reconhecer que aquele "algo" que é legal, essencialmente o agrada. A palavra LEGAL obteve $22 \%$ das escolhas da turma. De fato, esse é um percentual relativamente baixo, pois pouco mais de 1/5 dos estudantes 
avalia a atividade com o termo que reconhece um celular, um brinquedo, um passeio de seu desejo, enfim, a atividade remete ao sentido de motivador, agradável, que enriquece sua pessoa, sua vida.

Alves e Bianchin (2010) observam que esses aspectos (alguns apresentados acima), também, qualificam o jogo para a criança. Trata-se do fulcro da própria definição do termo em sua raiz latina, a designação "ludus" que significa diversão, brincadeira e, que é tido como um recurso capaz de promover um ambiente planejado, motivador, agradável e enriquecido, possibilitando a aprendizagem de várias habilidades.

Adicionalmente ao resultado obtido acima está a palavra DIVERTIDO. Cerca de $14 \%$ dos estudantes reconhecem as atividades como tal. Ela, semelhantemente à anterior, LEGAL, remete a uma ideia agradável e motivadora, porém ela é bem mais específica ao jogo. O jogo, para a criança, tem a função de divertir, entreter, alegrar, e, também, educar, estimular a aprendizagem. A brincadeira, portanto, estabelece uma dupla função quando exercida pela criança, e, essa dupla função, para os autores da presente pesquisa, é bem representada pelas palavras divertir e educar. Elas representam toda a miríade de possibilidades da brincadeira.

Essa visão implica que a brincadeira irá inserir a criança em um universo maior do que ela mesma, como afirma Vygotsky (2007, p.122), e, consequentemente trará a ela não somente uma nova dimensão comportamental, mas também, acerca de suas necessidades e consciência diante de sua existência. Dessa forma é na brincadeira que:

(...) a criança se comporta além do comportamento habitual de sua idade, além de seu comportamento diário. A criança vivencia uma experiência no brinquedo como se ela fosse maior do que é na realidade... O brinquedo fornece estrutura básica para mudanças das necessidades e da consciência da criança.

É notório que, ao observar em conjunto, o uso das palavras LEGAL e DIVERTIDO, cerca de $36 \%$ das escolhas, elas esclarecem o significado da atividade para os estudantes da Escola A. E, também, possibilita especular acerca do significado da escolha de $64 \%$ dos estudantes, que consideraram a atividade como INTERESSANTE.

Não raro, no cotidiano de acompanhamento da prática docente, é observado os professores afirmarem que durante as séries finais do Ensino Fundamental as 
crianças parecem, gradativamente, perder o interesse pelos estudos. Esse é de fato um assunto complexo por demais e foge ao escopo do presente trabalho, mas um aspecto dele será utilizado para ampliar as reflexões anteriores. Esse aspecto é a curiosidade do estudante.

Crianças por natureza são curiosas. A sobrevivência do ser humano urge pelo conhecimento do mundo que o rodeia, e, uma emoção importante que desvela essa situação é a curiosidade. $\mathrm{E}$, a curiosidade tem uma relação direta com uma atitude investigativa em relação ao mundo.

De acordo com De Paula e Harres (2015) a ciência é uma atividade baseada em uma emoção humana básica que é a curiosidade, e, essa emoção, as autoras procuram respaldar seus argumentos na obra do epistemólogo Humberto Maturana. Maturana define que ao buscar o conhecimento e a aprendizagem, o domínio de ação emocional em que se está é o da curiosidade, ou a paixão pelo explicar. Acerca desse aspecto, os escritos do próprio Maturana (2001, p.132) esclarecem:

A emoção fundamental que especifica o domínio de ações no qual a ciência acontece como uma atividade humana é a curiosidade, sob a forma do desejo ou paixão pelo explicar. Além disso, o que constitui a ciência como um tipo particular de explicação é o critério de validação que nós cientistas usamos, explícita ou implicitamente, para aceitarmos nossas explicações como explicações científicas ao praticarmos a ciência sob a paixão do explicar.

Nesse ponto, entende-se, e, defende-se, no presente trabalho, que os estudantes ao classificarem as atividades de INTERESSANTE possam estar indicando que a atividade desperta sua curiosidade, e lhes acende tal emoção, que os dirige para, de maneira mais ampla, compreendê-la como, também, LEGAL e DIVERTIDA. Dessa forma, os estudantes que assim classificam as atividades, também, cursam o $6^{\circ}$ ano do Ensino Fundamental, e, que estariam em uma zona de transição daquela apontada anteriormente, nesse trabalho, pela prática docente cotidiana, como caminhando para certa apatia (desinteresse) pelo conhecimento. Esses estudantes, em específico, parecem identificar no Jogo da Memória, uma brincadeira que remete ao rol de emoções que auxiliam o espírito investigativo tão presente nas ciências. A figura 07 ilustra as respostas dos estudantes da Escola A. 
Figura 7: Unidades de Registro para a Percepção dos Estudantes - Escola A.

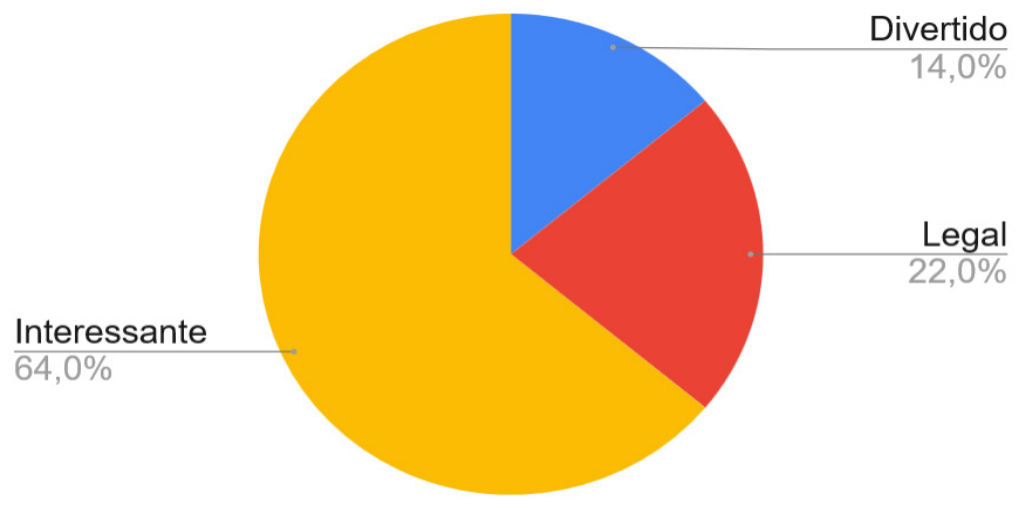

Ao analisar-se, comparativamente, os dados obtidos com os estudantes da Escola $\mathrm{B}$, o padrão de respostas, a princípio, parecem distintos dos apresentados para a Escola A.

Os estudantes da Escola B, diferentemente dos estudantes da Escola A, deixaram a palavra INTERESSANTE com o menor percentual entre o grupo das três palavras analisadas anteriormente, com apenas $13 \%$. Entretanto, as duas outras palavras, LEGAL e DIVERTIDO, apresentam uma soma total ainda maior que da palavra com escolha majoritária na Escola A, cerca de 70\% das escolhas, apontando o caráter já explorado acerca da perspectiva da atividade ser agradável, motivadora e, também, que oferece subsídios para educar. A figura 08 ilustra as respostas dos estudantes da Escola B.

Figura 8: Unidades de Registro para a Percepção dos Estudantes - Escola B

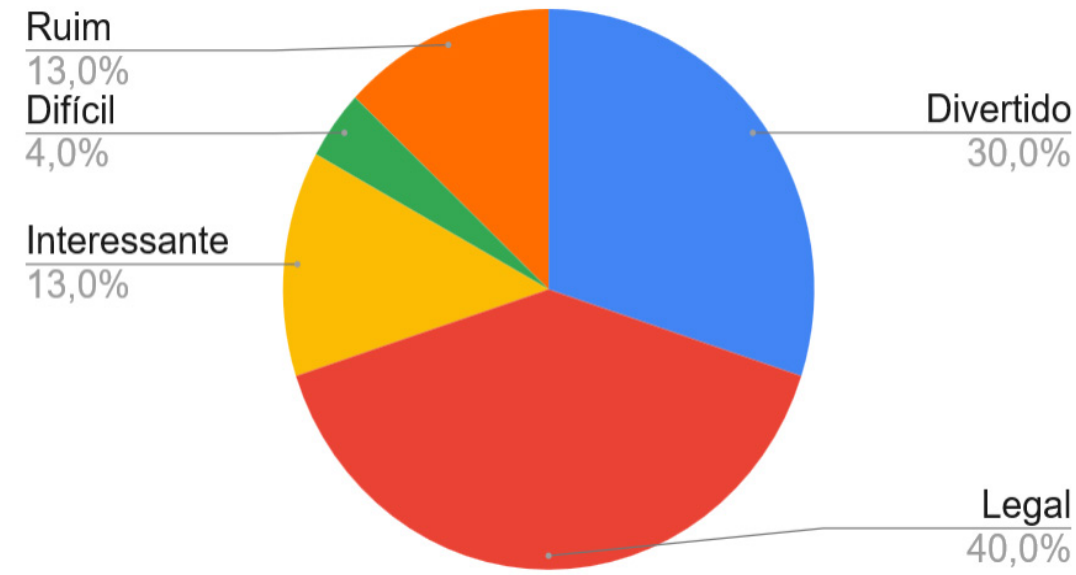


Adicional aos argumentos anteriores, observa-se que, outra diferença marcante é a escolha da opção RUIM pelos estudantes da escola B, 13\% das respostas. Esse resultado, não deixa dúvidas, que não se trata da dificuldade da atividade, porque eles poderiam ter optado pela palavra DIFÍCIL, que se diga de passagem, obteve um baixo percentual, apenas um único estudante em ambas as escolas.

A explicação é que esse grupo de estudantes que optou por RUIM não gostou da atividade. É necessário aprofundar a pesquisa nesse aspecto, mas a hipótese é que esses estudantes, possivelmente, não compreenderam o jogo proposto como essencialmente lúdico. $\mathrm{O}$ simples fato de ser um jogo não significa que basta para ser visto por todos os estudantes como algo lúdico.

Essa argumentação é apresentada por Brougère (1998, p.114):

O que caracteriza o jogo é menos o que se busca do que o modo como se brinca, o estado de espírito com que se brinca. Isso leva a dar muita importância à noção de interpretação, ao considerar uma atividade como lúdica. Quem diz interpretação supõe um contexto cultural subjacente ligado à linguagem, que permite dar sentido às atividades. O jogo se inscreve num sistema de significações que nos leva, por exemplo, a interpretar como brincar, em função da imagem que temos dessa atividade

Portanto, é possível que alguns estudantes tenham a imagem estigmatizada da matemática refletida no jogo da memória, e dessa maneira, a atividade não seria vista como lúdica, mas como uma das "exigências da matéria de matemática".

A Escola B, diferente da Escola A, funciona em tempo integral para desenvolver a Educação Integral. É sabido que a implantação de escolas nessa modalidade é recente em Mato Grosso do Sul, e os próprios professores ainda estão se adaptando a essa nova maneira de fazer Educação. Uma pergunta que precisa ser respondida é se essa nova escola não estaria apenas ampliando a carga horária, mas reproduzindo o mesmo modelo de ensino.

Em nome do uso de novos métodos, se estaria apenas exacerbando o uso de espaços como a sala de tecnologia, que, sem uma mudança evidente no paradigma de trabalho, pouco mudaria a percepção dos estudantes sobre o que se aprende, sobre o espaço da sala de aula (seja ela com ou sem computador). O modelo de mais carga horária logo pode se esgotar, resultando em desinteresse e atenuação da curiosidade pelas atividades em sala de aula. É possível que o ambiente de uso contínuo nessa escola da sala de tecnologia possa ter alterado sensivelmente a avaliação dos estudantes sobre a atividade desenvolvida, resultando nos $13 \%$ que optaram por INTERESSANTE. Entretanto, não é possível avaliar a dimensão do uso continuado 
de salas de tecnologia com os dados da presente pesquisa, até porque a soma das outras duas categorias, DIVERTIDO e LEGAL, na Escola B, somam expressivos 70\%.

De maneira geral, é possível afirmar com segurança, e os dados oferecem tal suporte, que os estudantes de ambas as escolas avaliaram o Jogo da Memória como possuidor das qualidades básicas de uma atividade de caráter lúdico para a idade deles e, que também, é uma ferramenta que possibilita ganhos para a aprendizagem.

O terceiro instrumento de avaliação da etapa sobre a percepção dos estudantes sobre o jogo da memória e atividades de matemática foi o Painel Palavra e Símbolo. $\mathrm{Na}$ atividade os estudantes realizaram a montagem de um painel e se apresentaram à frente (na lousa) mediante sorteio para identificarem a equivalência entre caracteres indo-arábicos e egípcios, bem como cálculos matemáticos.

A atividade exigiu do estudante, através da justaposição de pequenos recortes de papel, a confecção de um painel, uma espécie de tabela, em que os símbolos a serem explorados poderiam confirmar o planejamento da associação entre os caracteres egípcios, os indo-arábicos, as quantidades e operações matemáticas propostas pelo professor. A figura 09 ilustra um dos estudantes à frente no painel.

Figura 9: Estudante realizando a Atividade de Elaboração do Painel

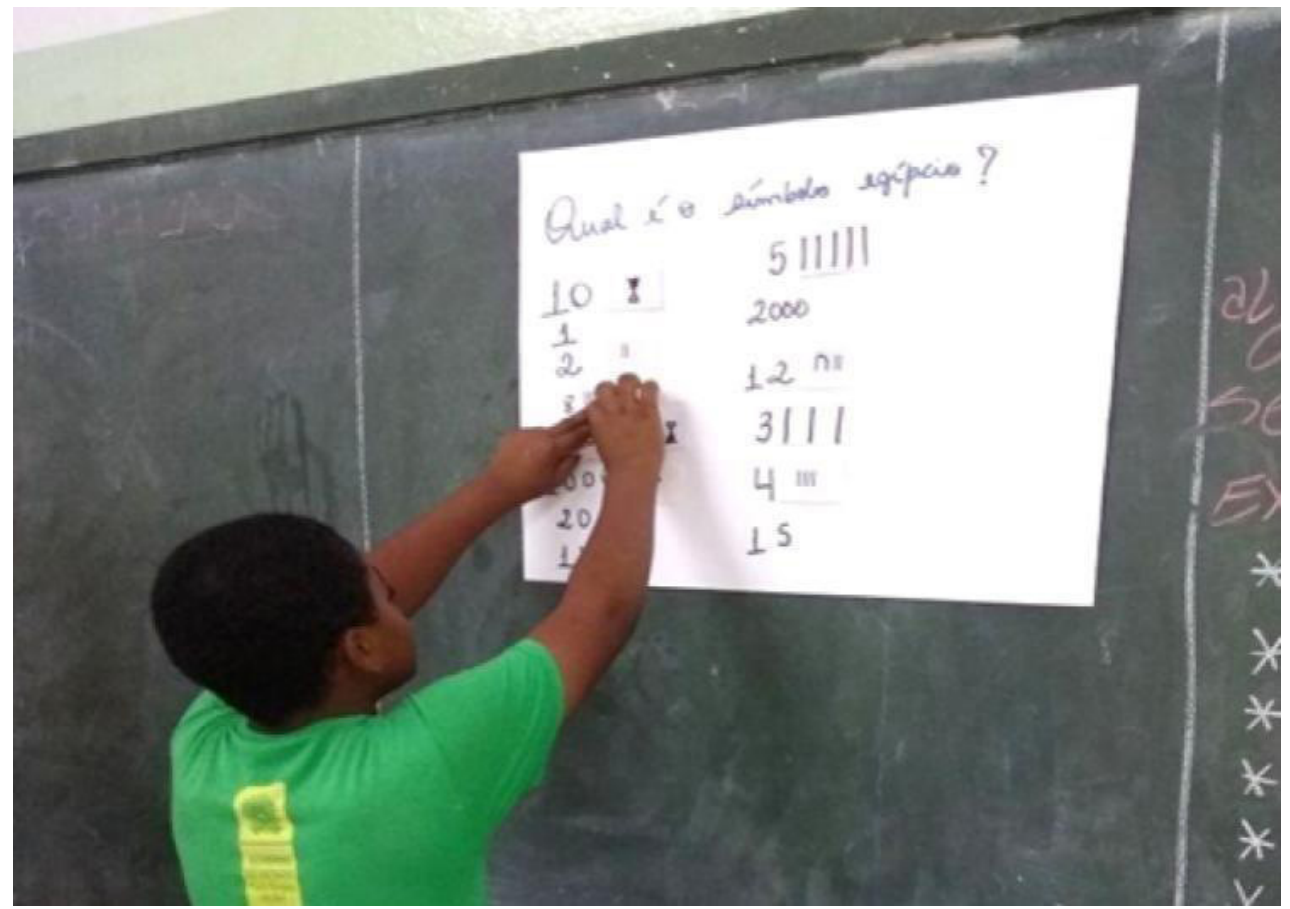


Os estudantes, de forma geral, demonstraram domínio tanto sobre a identificação quanto às operações matemáticas. $O$ destaque desta atividade foi o símbolo egípcio "flor de lótus", que representa a quantidade 1000 (mil). Esse símbolo gerou dúvidas quanto a seu uso. E, embora o seu desenho seja mais complexo, ele também representa uma quantidade maior comparativamente às demais utilizadas pelos estudantes durante o jogo.

Os resultados apresentados acima correspondem aos dados obtidos no primeiro momento da pesquisa, em fevereiro. A seguir, são apresentados os resultados das atividades do segundo momento, em junho, que foram aplicadas nas mesmas escolas às mesmas turmas. Nessa etapa, após cerca de 120 dias do primeiro contato com o jogo da memória, os estudantes participaram do que foi designado por Jogo da Memória: Cartas Virtuais, Cruzadinha e Quiz. A concepção dessas novas atividades consideraram os resultados e reflexões oriundas das intervenções anteriores. E, foram organizadas em uma sequência didática, cujos resultados de sua aplicação serão expostos em seguida.

As Cartas Virtuais correspondem ao Jogo da Memória Virtual. As regras são as mesmas, porém, utilizando um número maior de caracteres, com incremento da complexidade em relação à primeira versão, sendo que as rotinas consideram apenas operações matemáticas.

Os resultados foram semelhantes em ambas as escolas. Cerca de $60 \%$ dos estudantes ao jogar realizaram entre quinze e vinte e cinco jogadas para concluir o jogo, uma quantidade significativamente menor comparativamente à primeira versão online. Esse dado indica que mais da metade dos estudantes adquiriram a habilidade de identificar a troca simbólica entre os algarismos indo-arábicos e os egípcios, exigindo menor tempo e número de jogadas para a integralização do jogo.

Notou-se, que cerca de $12 \%$ dos estudantes (escolas A e B) fizeram uso de tempo adicional para integralizar o jogo. Entretanto, o número de jogadas necessárias para esse grupo de estudantes, na média, pouco se alterou em relação aos resultados da primeira versão do jogo da memória virtual, oscilando entre trinta e seis e cinquenta e cinco jogadas. A figura 10 ilustra um grupo de estudantes realizando o jogo Cartas Virtuais. 
Figura 10: Estudantes realizando rotinas do Jogo Cartas Virtuais.

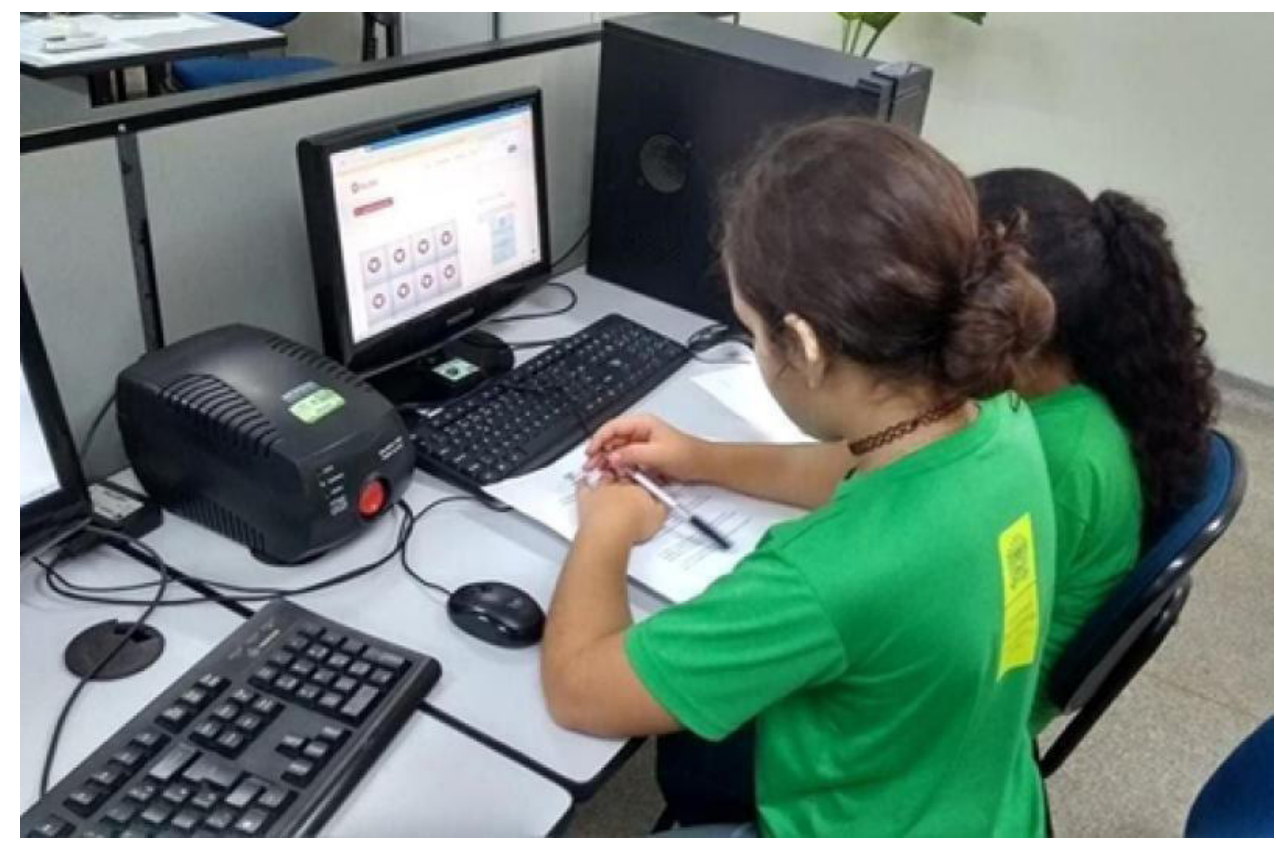

De maneira conclusiva, ao se comparar os resultados da primeira versão do jogo da memória virtual e o jogo Cartas Virtuais, é notório que na medida que a complexidade de caracteres envolvidos na carta se eleva o número de jogadas também sofre incremento.

Esse comportamento ficou evidente nos resultados da primeira versão virtual, em que durante a realização da segunda fase do jogo, que utilizava exclusivamente as operações matemáticas (semelhantemente às Cartas Virtuais), o percentual de estudantes que necessitavam de tempo adicional para integralizar o jogo oscilou entre 50\% (Escola B) e 67\% (Escola A), enquanto no jogo Cartas Virtuais esse percentual permaneceu pouco acima de 10\%, em ambas Escolas, porém com a mesma faixa de número de jogadas.

Atribui-se a queda significativa do número de estudantes que fizeram uso de tempo adicional para integralização do jogo com operações matemáticas (maior nível de complexidade) ao desenvolvimento (e estabilidade) da habilidade de identificar os caracteres e reconhecer as equivalências quantitativas desses caracteres. Na primeira intervenção verificou-se que os estudantes não possuíam experiências com 
as trocas simbólicas entre algarismos estudados, e mesmo as atividades propostas evidenciaram tal fato. Os resultados sugerem que o conjunto de atividades realizadas inicialmente com o Jogo da Memória Virtual e Físico, bem como o uso do Painel de Símbolos, tenham influenciado o desempenho dos estudantes no jogo Cartas Virtuais, mesmo 120 dias depois, ou ao menos, os estudantes demonstraram serem capazes de identificar e realizar as rotinas do jogo em menor tempo e com um número até 5 vezes menor de estudantes necessitando de tempo adicional para integralização.

Outra atividade desenvolvida e aplicada para verificar a compreensão dos estudantes sobre o jogo da memória foi a chamada Cruzadinha.

A Cruzadinha era composta por seis perguntas conforme ilustra a figura 11, extraída diretamente do recorte de um formulário aplicado. Ao lado, também na figura 11, um fragmento do formulário de resposta preenchido por um estudante.

Figura 11: Recortes dos Formulários de Perguntas e de Respostas de um dos estudantes.

\section{Cruzadinha}
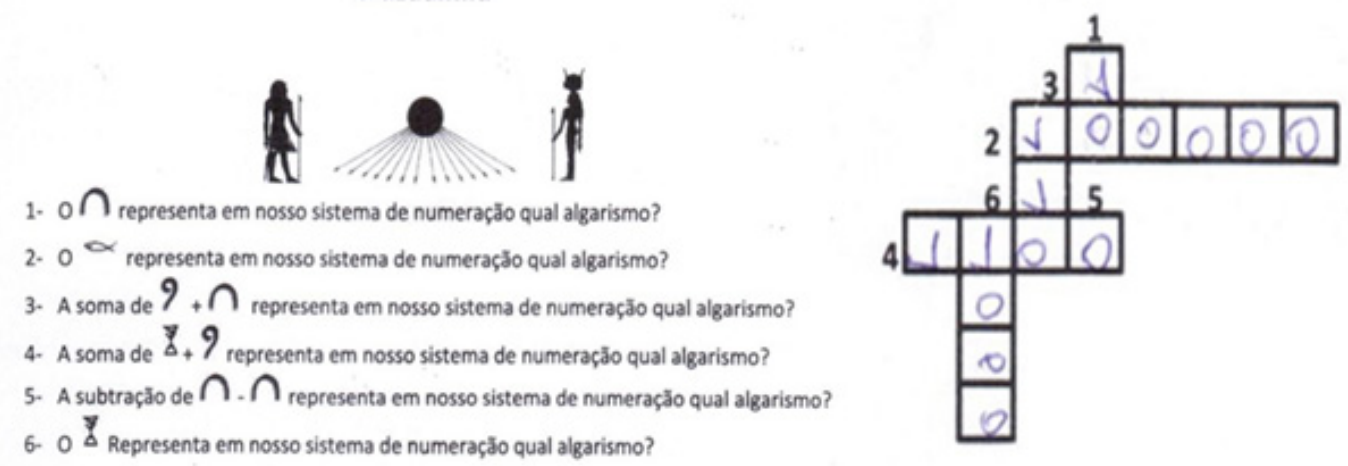

O comportamento das respostas dos estudantes foi semelhante ao longo de quatro das seis questões. As questões 1, 2, 5 e 6, tiveram todas o percentual de acerto de $92 \%$ dos estudantes, que correspondeu a 22 estudantes. $\mathrm{O}$ algarismo egípcio que equivale a dez no sistema indo-arábico possui traços simples, fazendo lembrar a letra "C" para baixo, ou mesmo uma ferradura. O propósito da questão era verificar se os estudantes seriam capazes de identificar esse algarismo e relacioná-lo com uma quantidade relativamente pequena e de uso cotidiano, possível de ser contabilizado pelas próprias mãos. 
A questão 2, semelhante à primeira, tinha por objetivo verificar a habilidade do estudante de identificar o símbolo egípcio no sistema indo-arábico. $\mathrm{O}$ algarismo egípcio selecionado na questão dois é um pouco mais elaborado que o número 10 , ele tem a forma de um peixe, cujo valor no sistema de numeração indo-arábico equivale à quantidade 100.000. Embora o símbolo utilizado seja familiar, um peixe, a quantidade é relativamente elevada, distante do universo cotidiano dos estudantes, porém, esse algarismo foi reconhecido e associado à quantidade correta por $92 \%$ dos estudantes.

Embora com um percentual levemente menor em relação às questões $1 \mathrm{e} 2$, os acertos da questão 3 (88\%) confirmam que os estudantes reconhecem os símbolos egípcios e são capazes de realizar a correspondência com as quantidades que eles representam no sistema indo-arábico. A variação no percentual de erros de $12 \%$ não é suficiente para especular sobre as dificuldades acrescidas pela inserção do símbolo de soma na operação.

A Questão 4 se refere a uma soma de dois símbolos egípcios, semelhante à questão 03. A soma de ambos algarismos corresponde à quantidade 1100 no sistema indo-arábico. O resultado indica que apenas um único estudante conseguiu responder corretamente à questão (96\% de erros), sendo evidente a dificuldade em identificar ambos ou um dos símbolos egípcios. Entretanto, um dos algarismos egípcios, presentes na questão 4 , aquele que tem como ícone um rolo enrolado ou a quantidade 100, foi reconhecido majoritariamente na questão 03 (88\% de acertos). Ao que parece, a flor de lótus, que representa a quantidade 1000 escapou à memória dos estudantes, ou, possivelmente, a correspondência desse ícone com a quantidade que ela equivaleria no sistema indo-arábico não foi corretamente estabelecida.

É possível, também, que os estudantes não estejam necessariamente fazendo uso do raciocínio lógico matemático ao responder à questão. Os estudantes poderiam estar realizando determinado algoritmo matemático, mas não o compreender de fato. As autoras Kamii e Declark (1991, p. 93) afirmam que "aprender a somar, subtrair e multiplicar, no entanto, envolve um raciocínio lógico matemático, e raciocínio não é técnica. O raciocínio não se desenvolve e nem pode ser aperfeiçoado meramente através da prática". Nesse caso, a explicação que remete ao trabalho pedagógico do professor de "Ensinar" pode ter papel de destaque para engendrar o estudante por dentro da lógica de somar ou subtrair. 
As reflexões anteriores parecem amparar de maneira mais intensa parte das respostas dos estudantes na questão 5 . Nesta questão é proposta a subtração que faz uso do mesmo algarismo egípcio da Questão 1, porém ele é repetido e posicionado antes e depois do sinal de subtração, o que implica que o resultado será nulo, isto é, zero.

De maneira geral, os estudantes foram capazes de identificar e solucionar a operação matemática de subtração. Entretanto, ao observar a questão 01, onde os percentuais são exatamente os mesmos (92\% acertos, $8 \%$ erros), se poderia especular se os estudantes que não identificaram e não estabeleceram correspondência quantitativa entre os algarismos egípcios e indo-arábicos na questão 01 seriam os mesmos que erraram a questão 05 . $\mathrm{E}$, de fato são, conforme a identificação numérica dos formulários. É relevante salientar que os estudantes não se atentaram para o fato de que não seria necessário realizar a identificação e correspondência dos algarismos indo-arábicos e egípcios, bastando para tanto apenas compreender que independentemente da quantidade que o símbolo representa, uma vez reconhecida a operação matemática (subtração), a conclusão é que o algarismo sendo o mesmo, ocorre a anulação da quantidade.

Em relação à Questão 6, a pergunta se referia ao estudante identificar a flor de lótus e reconhecer sua correspondência com a quantidade 1.000 no sistema de numeração indo-arábico. Apenas $8 \%$ dos estudantes erraram essa questão. Entretanto, a flor de lótus, hipoteticamente seria a razão de $96 \%$ dos estudantes terem errado a operação matemática que envolvia a soma simples entre o algarismo identificado na Questão 3 por 88\% dos estudantes (o algarismo egípcio 100) e a própria flor de lótus.

Ao cruzar as informações das Questões 01, 03 e 06, parece ser conclusivo que os estudantes certamente poderiam ter solucionado a operação da questão 04, uma vez que os mesmos ícones (de maneira individual) são identificados e a correspondência de suas respectivas quantidades são reconhecidas.

A terceira atividade proposta do segundo momento foi o Quiz. Esse jogo de perguntas e respostas, de maneira semelhante aos anteriores, avaliou, também, a habilidade dos estudantes em identificar algarismos egípcios e reconhecer sua correspondência com algarismos indo-arábicos, porém partindo dos algarismos indo-arábicos como referência, isto é, o caminho inverso ao jogo da Cruzadinha. Os resultados têm como indicador as unidades de registro "Acerto" e "Erro", expressos em percentuais, isto é, a frequência. A tabela 03 ilustra as questões do Quiz e o 
percentual de acertos e erros. Adicionalmente, foi admitido a possibilidade dos estudantes deixarem sem resposta a questão, caso entendessem que não soubessem a resposta correta.

Tabela 3: Respostas dos Estudantes ao Quiz.

\begin{tabular}{l|r|r|r}
\multicolumn{1}{c|}{ Questões } & $\begin{array}{c}\text { Acertos } \\
\%\end{array}$ & \multicolumn{1}{c|}{$\begin{array}{c}\text { Erros } \\
\%\end{array}$} & $\begin{array}{c}\text { Sem Resposta } \\
\%\end{array}$ \\
\hline Como é representado 1 (um) em algarismo egípcio? & 75 & 17 & 8 \\
\hline $\begin{array}{l}\text { Que símbolo representa as 10 (dez) ovelhas que um pastor } \\
\text { egípcio comprou? }\end{array}$ & 59 & 33 & 8 \\
\hline $\begin{array}{l}\text { Qual a quantidade que a flor de lótus representa como símbolo } \\
\text { egípcio? }\end{array}$ & 25 & 58 & 17 \\
\hline
\end{tabular}

A primeira questão foi elaborada com pressuposto que a identificação e correspondência da unidade em cada sistema numérico, por serem semelhantes, poderia ser considerada de baixo grau de dificuldade. Como resultado $75 \%$ dos estudantes acertaram a questão, o que é significativo. Contudo, considerando o baixo grau de dificuldade, especialmente, em razão da unidade em ambos sistemas simbólicos serem representados, respectivamente, pelos caracteres “1” (indo-arábico) e “ $\square$ ” (egípcio), que em si, carregam a ideia da quantidade una, o que qualifica como expressivo os $17 \%$ de estudantes que erraram e, adicionalmente, outros $8 \%$ que não souberam responder à questão.

A segunda pergunta do Quiz é formulada utilizando a ilustração de um pastor com suas ovelhas, em uma tentativa de estabelecer uma imagem para auxiliar o estudante a pensar no problema a partir de um contexto. A questão propõe a identificação e reconhecimento do número " 10 ” do sistema numérico indo-arábico para o egípcio, uma quantidade cotidiana e que na Cruzadinha obteve $92 \%$ de acerto. O resultado do Quiz aponta que 59\% dos estudantes acertaram a questão; outros $33 \%$ erraram e $8 \%$ não souberam responder. Essa questão, entre todas, é a que apresenta o maior número de erros, 1/3 dos estudantes, o que implica, a princípio, dificuldade desses estudantes em identificar e reconhecer a correspondência entre os símbolos egípcios, o que é contraditório em relação ao resultado da Cruzadinha.

O Quiz retoma a questão da identificação e a quantificação da flor de lótus. Os resultados indicam que $25 \%$ acertaram a quantidade que a flor de lótus representa, enquanto outros $58 \%$ assinalaram outras respostas acreditando estarem corretos. Os 
estudantes que admitiram que não sabiam identificar a flor de lótus foram $17 \%$. O algarismo egípcio que tem como símbolo a "flor de lótus" representa o número 1.000 no sistema indo-arábico, esse algarismo egípcio nitidamente é mais bem elaborado do que os outros dois das questões 01 e 02.

Seria a complexidade do símbolo a razão do acentuado percentual de erros? Seguramente não. Os resultados obtidos com o Jogo da Memória indicam que o processo de identificação dos símbolos é indiferente a seu registro (seu desenho) em si, e, que em geral, quando os estudantes se apropriam da habilidade de identificarem e reconhecerem a correspondência quantitativa entre os símbolos, também, passam a diferenciarem e perceberem, com maior clareza, que os símbolos são meras representações, isto é, eles substituem ou tomam o lugar de algo, e que, o representado está além do mundo simbólico, o objeto de conhecimento, o objeto matemático, a quantidade.

É certo que as questões do Quiz apresentaram um percentual de erros superior aos do Jogo da Cruzadinha. Ao analisar suas diferenças mais evidentes, duas merecem destaque.

Uma diferença marcante entre os jogos é a sequência exigida para a identificação e correspondência simbólica. Na Cruzadinha os símbolos egípcios são apresentados e os estudantes identificam sua forma indo-arábica; diferentemente, no Quiz, os símbolos indo-arábicos são apresentados e os estudantes identificam sua forma egípcia.

Outra diferença é que enquanto no Quiz perguntas são apresentadas individualmente, e a resposta, também, é registrada separadamente das demais. $\mathrm{Na}$ Cruzadinha há o entrelaçamento entre perguntas, que estão no mesmo formulário. As respostas devem ser registradas em uma estrutura de grade que graficamente permite o estudante correlacionar perguntas e respostas, devido o número de dígitos que podem ser inseridos na grade.

\section{Percepção dos Estudantes sobre o Jogo de Cartas Virtuais}

Os estudantes avaliaram o Jogo Cartas Virtuais, que, semelhantemente ao Jogo da Memória Virtual (primeira etapa da pesquisa), explorou a identificação de algarismos indo-arábicos e sua correspondência com numerais egípcios, porém, focando principalmente na resolução de operações matemáticas. 
Para compreender, na perspectiva dos estudantes, as visões de desenvolveram sobre o Jogo Cartas Virtuais foi solicitado que escolhessem uma única palavra, ou unidade de registro, que melhor representasse suas impressões sobre a atividade. Diferente da primeira avaliação em que os estudantes foram estimulados a escolher uma entre cinco palavras propostas, nessa avaliação eles ficaram livres para apontar a palavra que, no entendimento deles, mais bem representa sua experiência com o jogo realizado.

Verificou-se que $92 \%$ dos estudantes classificaram o jogo com diferentes palavras, mas que podem ser reunidas em uma única categoria que avalia a atividade como "Prazerosa" ou "Agradável" de ser realizada, conforme as unidades de registro: BOM, LEGAL, MUITO BOM, INTERESSANTE, DIVERTIDO, MUITO IRADO, que fazem parte do seu vocabulário informal. Somente 8\% dos estudantes (dois) consideraram a atividade DIFÍCIL ou CONFUSA.

Uma das declarações merece destaque. A unidade de registro "FOI UM DIA DIFERENTE", contempla e reforça a tese de que as atividades atingiram seu objetivo central de provocar o estudante, causando desequilíbrio e chamando sua atenção. Em certa medida ao jogar o jogo o estudante o contrapôs a outros momentos em sala de aula, reconhecendo que o jogo proposto para auxiliar na aprendizagem de matemática alcançou seu objetivo também como instrumento motivacional e de caráter lúdico para o estudante.

De outra maneira, as atividades que fazem uso do jogo como recurso pedagógico rompem com o paradigma presente no cotidiano do estudante, o que não significa afirmar que as atividades do cotidiano não sejam planejadas ou mesmo de menor qualidade ou ainda desmotivadoras, mas que o fato de uma atividade educacional valorizar o caráter lúdico e o uso de espaços no âmbito escolar que incluem a tecnologia (computador) tão familiar na sociedade atual, se configurou, se revelou como um instrumento que lançou luz sobre a atenção do estudante para o aprendizado da matemática.

Segundo Demo (2002, p. 76), a Matemática é considerada o "bicho-papão", na qual o professor repassa informações, os alunos tomam nota, memorizam e depois reproduzem em uma avaliação, elaborando uma percepção de que a Matemática seja algo difícil e incompreensível.

É evidente que qualquer campo de conhecimento possui suas complexidades. Torna-se relevante no planejamento de atividades que pressupõem serem capazes 
que auxiliar na aprendizagem do estudante, considerar (entre outros aspectos, ex. epistemológico) que a seleção dos recursos pedagógicos possam atenuar (ou mesmo evitar) que se estabeleça bloqueios ou urgir estereótipos desmotivadores desnecessários, que, ao contrário do que o senso comum faz acreditar, termos como "bicho-papão", "matéria difícil”, entre outros, acabam por reduzir o valor dessa área de conhecimento na perspectiva do estudante. (DEMO, 2002, p.76)

A figura 12 ilustra as unidades de registro escolhidas pelos estudantes, bem como sua frequência (representada pela divisão espacial) para expressar sua vivência com o Jogo Cartas Virtuais.

Figura 12: Avaliação dos estudantes sobre o Jogo da Memória.

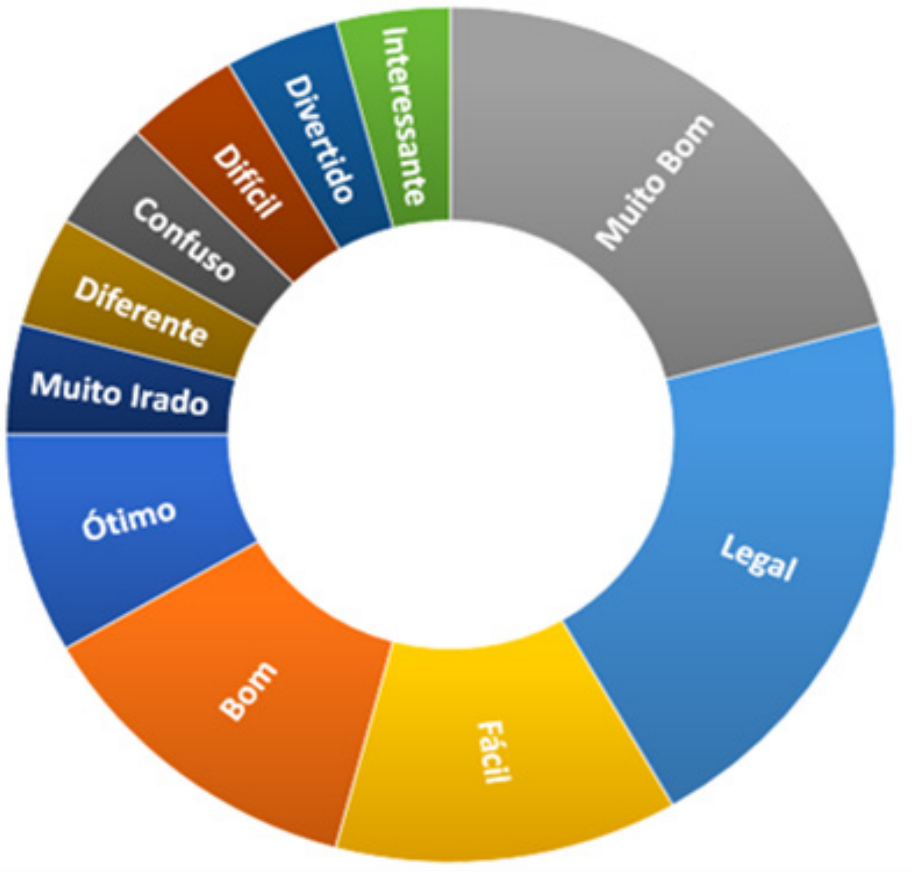

É necessário ampliar a reflexão sobre novas práticas (que envolvam ou não tecnologias), novos espaços (físicos ou virtuais), e, implementar através do planejamento, tal como a organização de uma sequência didática, atividades que auxiliem tanto no ganho cognitivo quanto no desenvolvimento de aspectos socioemocionais. E, embora, a motivação, por exemplo, embora sozinha não possa transformar o aprendizado de matemática do estudante, por outro lado, um estudante motivado é 
um indicador seguro de maiores chances das atividades propostas terem a atenção, o cultivo e fomento de momentos de reflexão por parte dos estudantes sobre o que lhes é proposto.

Após apresentar o conjunto de resultados dos dois momentos da investigação, e, respeitando a técnica utilizada para análise de conteúdo escolhida, a análise categorial, foi possível elaborar duas categorias (Desempenho e Interesse) que foram forjadas a partir da análise do conjunto de unidades de registro propostas inicialmente.

A categoria "Desempenho" agregou o conjunto de significações das unidades de registro presentes nos dois momentos da investigação. Nas atividades do Jogo da Memória Virtual e do Jogo Cartas Virtuais a escolha das unidades de registro número mínimo de jogadas e número máximo de jogadas estavam articuladas com as unidades de registro acertos e erros dos jogos de Cruzadinha e Quiz. A expectativa inicial era de que esse conjunto de dados (unidades de registro) permitissem, através da análise de seus comportamentos quantitativos, afirmar que o aproveitamento dos estudantes nas atividades propostas poderiam ser qualificadas como recursos pedagógicos que prestam auxílio à aprendizagem de matemática.

Através das unidades de registro número mínimo/máximo de jogadas foi possível verificar, nas respostas dos estudantes que:

1) a frequência de identificação dos algarismos egípcios elevou-se entre os dois momentos da pesquisa;

2) a correspondência simbólica entre os sistemas de algarismos indo-arábicos e egípcios apresentou melhores índices no segundo momento da investigação;

3) os estudantes apresentaram melhor aproveitamento nos jogos que valorizam mais a identificação na troca simbólica do que quando envolvem o uso de operações matemáticas;

4) o percentual de estudantes que necessitavam de tempo adicional para concluir jogos com uso de operações matemáticas foi reduzido em cinco vezes no segundo momento do trabalho;

5) o tempo e o número de jogadas necessárias para concluir o jogo da memória sofreu redução para mais de $60 \%$ dos participantes;

6) embora o número de estudantes que usassem de tempo adicional para concluir o jogo foi significativamente reduzido, o número de jogadas permaneceu o mesmo nos dois momentos da pesquisa. 
As unidades de registro acertos e erros possibilitou verificar, nas respostas dos estudantes, que:

1) a maior parte dos estudantes identificam os algarismos egípcios e suas respectivas quantidades;

2) a maioria dos estudantes conseguem realizar a troca simbólica entre os algarismos egípcios e indo-arábicos;

3) parte significativa dos estudantes conseguem efetuar operações matemáticas com os algarismos egípcios;

4) dificuldades de identificação dos algarismos egípcios é crescente com complexidade icônica;

5) Menos de $10 \%$ dos estudantes apresentaram dificuldades consideráveis para identificar e realizar operações matemáticas.

A categoria "Interesse" foi a resposta à análise das unidades de registro na forma de palavras. Os estudantes escolheram, individualmente, uma única palavra para expressarem sua percepção acerca do Jogo da Memória Virtual, em fevereiro, e, uma outra palavra para o Jogo Cartas Virtuais, em junho.

$\mathrm{Na}$ avaliação do jogo da memória em fevereiro, o primeiro conjunto de unidades de registro apresentavam 5 palavras, sendo 3 delas expressando caráter positivo em relação à atividade. Essas palavras foram definidas pelos pesquisadores e os estudantes não poderiam adicionar nenhuma ao grupo.

$\mathrm{Na}$ avaliação do jogo da memória em junho, o segundo conjunto de unidades de registro eram compostas, exclusivamente, com palavras sugeridas pelos estudantes. Foram catalogadas 11 palavras. Foi identificado que 4 das 5 palavras da primeira pesquisa estavam presentes nas escolhas dos estudantes, e, que 3 delas expressavam o caráter positivo em relação ao jogo. Outras 6 palavras entre as 11 indicavam, igualmente, uma visão positiva em relação às atividades.

Esse caráter positivo em relação ao jogo permaneceu com percentuais acima de $90 \%$ das escolhas dos estudantes, em ambas as escolas, nos dois momentos da pesquisa.

Ao analisar o conjunto das unidades de registro é possível agrupá-las em pequenos blocos: 
1) Divertido, Legal e Interessante: estavam presentes nos dois momentos da pesquisa e de acordo com sua frequência significativa e as análises anteriores representam para os estudantes a expressão lúdica do jogo;

2) Bom, Muito Bom, Ótimo: foram sugeridas pelos estudantes e representam $50 \%$ das escolhas. São palavras utilizadas comumente na escola para expressar qualitativamente que uma determinada atividade possui mérito;

3) Muito Irado e Diferente: expressam que o jogo quebra do padrão do tipo de atividade que o estudante está acostumado cotidianamente;

4) Difícil e Confuso: a palavra difícil estava presente em ambos os momentos da pesquisa, mas na primeira não foi escolhida por nenhum estudante; na segunda foi escolhida, a exemplo da palavra confuso, por um único estudante;

5) Fácil: sugerida pelos estudantes, representou cerca de 1/6 das escolhas.

Foi a partir da consideração desses blocos que se definiu a ideia de que o conjunto das unidades de registro expressavam em uma só categoria o "interesse" do estudante pela atividade, seja pelo seu caráter lúdico ou intuitivo e simples, ou ainda porque proporciona prazer ao aprender.

Finalmente, é possível inferir, a partir da categoria Desempenho, que o jogo da memória, nos limites que foram apresentados nessa proposta, contribuiu para a aprendizagem de matemática ao reafirmar aos conhecimentos de matemática dos estudantes do sexto ano do Ensino Fundamental a habilidade de identificar algarismos egípcios e suas quantidades, bem como realizar a correspondência com algarismos indo-arábicos e operações matemáticas básicas. Também, foi possível inferir, a partir da categoria "Interesse", que o jogo da memória apresentou caráter lúdico e motivacional, permitindo aos estudantes tecer um novo olhar sobre as possibilidades do jogo para aprender matemática.

\section{Considerações finais}

As reflexões oferecidas nesse artigo procuraram responder à questão: O Jogo da Memória com uso de imagens (algarismos egípcios/indo-arábicos) pode ser considerado um recurso pedagógico que auxilia na aprendizagem de matemática? 
Para responder a essa indagação foram elaboradas atividades que envolveram estudantes do $6^{\circ}$ ano do Ensino Fundamental, de duas escolas estaduais do município de Campo Grande-MS, em jogos com diferentes formatos que se baseiam no uso da memória. Esses jogos foram concebidos a partir de considerações de conhecimentos de matemática (operações básicas) e as possibilidades de aprendizagem das mesmas a partir do reconhecimento e trocas simbólicas entre representações numéricas indo-arábicas e egípcias.

O trabalho de investigação se dividiu em dois grandes momentos temporais, nos meses de fevereiro e junho de 2018. As atividades do mês de fevereiro se concentraram em identificar a capacidade dos jogos propostos (Jogo da Memória Virtual e Físico) de atrair a atenção dos estudantes (apresentar caráter lúdico) e verificar o desempenho dos mesmos como indicador de ganho cognitivo. Posteriormente, no mês de junho, atividades adicionais explorando pequenas mudanças no formato dos jogos, procuraram intensificar o contato dos estudantes com a proposta inicial, e retomar a verificação tanto do interesse quanto do desempenho dos estudantes frente aos conteúdos de matemática e aos recursos (jogos) utilizados.

É importante destacar que os estudantes diferenciam o espaço físico da sala de aula do espaço físico da sala de tecnologia, e, uma das razões consiste na abordagem presente nas atividades desenvolvidas, não necessariamente o espaço físico em si, sendo que quando essas atividades privilegiam a ação dos estudantes há maior engajamento e manifestação de interesse pelo aprendiz.

Outro aspecto observado é que o jogo em si, construído ou não pelos estudantes, apresenta caráter lúdico para os mesmos, isto é, os estudantes interpretam as diferentes atividades que envolvem modalidades de jogos de memória como possuidoras de uma dimensão de aprendizagem mais prazerosa, que naturalmente culminam em maior valorização dos conteúdos matemáticos envolvidos no cerne da organização de cada jogo proposto.

Os resultados da investigação apontam que os estudantes foram mais hábeis na identificação dos algarismos egípcios do que no uso desses algarismos para a resolução de operações matemáticas. Nos jogos da primeira etapa de atividades (em fevereiro de 2018), em ambas Escola A e B, respectivamente, 87\% e 75\% dos estudantes alcançaram êxito na identificação e correspondência entre os algarismos dos sistemas numéricos estudados. Na segunda etapa de atividades (em junho de 2018), os resultados, em ambas escolas, foram expressivos para a habilidade dos 
estudantes de identificação dos algarismos, cerca de 60\%, e, deve-se considerar que os algarismos eram maiores do que na primeira etapa, e, para esse grupo o número de jogadas ficou abaixo de 25 .

Comparativamente, na segunda etapa de atividades (após 120 dias), os estudantes demonstraram maior habilidade no jogo com as operações matemáticas, pois $12 \%$ dos estudantes necessitaram de tempo adicional e um número maior de jogadas para a integralização do jogo, esse resultado é contrastante com os $67 \%$ (Escola A) e 50\% (Escola B) durante a primeira etapa de atividades para o mesmo procedimento de resolução de operações matemáticas.

Alguns resultados, como os da Cruzadinha e do Quiz, na segunda etapa de atividades, parecem colocar em dúvida a tese defendida acima, porém, para os autores do presente trabalho, esses resultados eram esperados. As Cruzadinhas e o Quiz invertem a lógica de identificação e correspondência dos algarismos de ambos os sistemas indo-arábicos e egípcios, e na avaliação dos autores do presente trabalho, a estrutura da Cruzadinha permite ao estudante maiores oportunidades de trabalhar sua intuição devido à grade definir o número de dígitos da resposta, o que não é possível no Quiz.

Quanto ao aspecto de empatia, isto é, a percepção do estudante sobre as atividades dos jogos serem classificadas como prazerosas manteve-se com percentual superior a $90 \%$ em ambas as intervenções. É possível afirmar que para os estudantes desta pesquisa os jogos apresentados são identificados como atividades com caráter lúdico.

Finalmente, conclui-se que o jogo da memória, dentro dos limites apresentados nesta investigação, pode ser considerado um recurso pedagógico que contribuiu para a aprendizagem de conteúdos de matemática para estudantes do Ensino Fundamental das escolas que participaram do trabalho. Esse aprendizado tange ao uso de algarismos egípcios e suas trocas simbólicas com os indo-arábicos, bem como a realização de operações matemáticas básicas. 


\section{The game of memory as a pedagogical resource}

\section{Abstract}

For some decades, society has been undergoing a profound cultural transformation based on information technology. The intense use of technology is present in products, goods and services, whether for urban mobility, food production, sanitary control, medicine production, or personal use such as computers and mobile phones, increasingly present in young people's lives. This cultural change offers opportunities for learning mathematics in the school environment. Gambling, and therefore joke, is an important resource for enhancing student learning in elementary school. The present work investigated the elaboration of online and physical versions of the Memory Game and its use as a pedagogical resource to help the learning of mathematical concepts using the symbolic exchange between Indo-Arabic and Egyptian numerals. The research was conducted with students from two state schools in Campo Grande-MS. The results indicate that the gradual complexity of the characters and the requirement to perform mathematical operations can change the typology of student response. On the other hand, different activities, regardless of the use or not of computer science, enhance the learning of mathematical concepts and assimilation. of symbolic exchanges.

Keywords: Memory Game. Computer Science at School. Mathematics Learning. Egyptian Numerals.

\section{Referências}

ALVES, L.; BIANCHIN, M. A. O Jogo como Recurso de Aprendizagem. Revista Psicopedagogia. v. 27, e83, p. 282-287. 2010.

BARDIN, L. Análise de conteúdo. São Paulo: Edições 70, 2011.

BARDIN, L. Análise de conteúdo. São Paulo: Edições 70, 2016.

BAUER, A.; ALAVARSE, O.M.; OLIVEIRA, R.P. Avaliações em Larga Escala: Uma Sistematização do Debate. Educação e Pesquisa, São Paulo, v. 41, n. especial, p. 1367-1382, dez., 2015.

BAUMGARTEL, P. O Uso de Jogos como Metodologia de Ensino da Matemática. In: XX EBRAPEM - Encontro Brasileiro de Estudantes de Pós-graduação em Educação Matemática. Setembro, UFPR, Curitiba, 2016.

BRASIL. Base Nacional Comum Curricular. Educação Infantil. Brasília: MEC. CNE em 03 de abril de 2018. Link: http://basenacionalcomum.mec.gov.br/images/BNCC_EI_EF_110518_versaofinal_site.pdf. Acesso em: 03 setembro 2019.

BROUGERE, Gilles. A criança e a cultura lúdica. Revista da Faculdade de Educação, São Paulo, v. 24, n. 2, p. 103-116, July 1998.

COSTA, S. M. Jogos no Ensino de Matemática: Potencialidades e Desafios. In: CONEDU - Congresso Nacional de Educação, Outubro, Olinda, 2018.

CRUZ, R.P. Integrando Tablets na Disciplina de Matemática: Percepções dos Alunos da Educação Básica. 2016. 153. Dissertação (Mestrado em Ensino) - Centro Universitário Univantes, Lageado, 2016. 
DE PAULA, A. C.; HARRES, J.B.S. Teoria e Prática no "Educar Pela Pesquisa" Análise de Dissertações em Educação em Ciências. Revista Contexto e Educação. Unijuí. Ano 30, n. 96, maio/ago. 2015.

DEMO, Pedro. Educar pela pesquisa. São Paulo: Autores Associados, 2002.

KALINKE, M. A.; MOCROSKY, L.; ESTHEPHAN, V. M. Matemáticos, educadores matemáticos e tecnologias: uma articulação possível. Revista Educação Matemática Pesquisa, São Paulo, v. 15, n. 2, p. 359-378, 2013.

KAMII, C.; DECLARK, G. Reinventando a Aritmética - Implicações da Teoria de Piaget. Editora Papirus. Campinas. 1991.

KISHIMOTO, T. M. O jogo, brinquedo, brincadeira e a educação. São Paulo: Editora Cortez, 2007.

MATURANA, H. Cognição, Ciência e Vida Cotidiana. Organização e tradução Cristina Magro, Victor Paredes. - Belo Horizonte: Ed. UFMG, 203p. 2001.

NAGUMO, E.; TELES, L. F. O Uso do Celular por Estudantes na Escola: Motivos e Desdobramentos. Revista Brasileira de Estudos Pedagógicos. (online), Brasília, v. 97, n. 246, p. 356-371, maio/ago. 2016.

PIZARRO, M. V.; LOPES JUNIOR, J. Os Sistemas de Avaliação em Larga Escala e seus Resultados: O PISA e suas Possíveis Implicações para o Ensino de Ciências. Revista Ensaio Pesquisa em Educação em Ciências. v. 19, e. 2276, p.1-24, 2017.

REINALDO, F.; MAGALHÃES, D.R.; REIS, L. P.; GAFFURI, S.; FREDDO, A..; HALLA, R. Impasse aos Desafios do Uso de Smartphones em Sala de Aula: Investigação por Grupos Focais. Revista lbérica de Sistemas y Tecnologías de Información. RISTI, n. 19, p. 77-92, set. 2016.

RIBEIRO, J. C.; LEITE, L.; SOUSA, S. Notas sobre Aspectos Sociais Presentes no Uso das Tecnologias Comunicacionais Móveis. In: Educação e Contemporaneidade: Pesquisas Científicas e Tecnológicas [online]. p. 184-201. Salvador: EDUFBA. 2009.

ROMANELLO, L. A. O Celular como Recurso Didático nas Aulas de Matemática: a Visão do Professor. In: XX EBRAPEM - Encontro Brasileiro de Estudantes de Pós-graduação em Educação Matemática, Setembro, UFPR, Curitiba, 2016.

SALGADO, S. A. R. O Smartphone: Uma Ferramenta para a Educação no Ensino Superior da Cidade de Campinas - SP. 2018. 149. Dissertação (Mestrado em Educação) - Centro Universitário Salesiano de São Paulo, Americana, 2018.

SCHELLER, M.; SCHMITT, M.; SOUSA, A. P. P.; SCUSSEL, A. C. H. Jogos e Brincadeiras Propiciando o Desenvolvimento de Noções Matemáticas na Educação Infantil. Revista de Educação, Ciências e Matemática. v. 8, p. 118-136, 2018.

SILVA, A. K. A.; CORREIA, A. E. G. C.; LIMA, I.F. O Conhecimento e as Tecnologias na Sociedade da Informação. Revista Interamericana de Biblioteconomia. Medellín (Colombia) v. 33, n. 1, p. 213-239, enero-junio de 2010.

SILVA, L. P. Celular como Ferramenta de Ensino e Aprendizagem de Matemática. 2018. 88p. Dissertação (Mestrado Profissional em Matemática em Rede Nacional) - Universidade Federal de Rondônia, Porto Velho, 2018. 
SILVA, S. L. D.; SCHEFFER, N. F. O Jogo Digital on-line e as Funções Cognitivas de Atenção e Memória em Matemática: Um Estudo em Neurociências. Revista Brasileira de Ensino de Ciências e Matemática. Passo Fundo, v .2, n. 1, p. 150-171. jan./jul. 2019.

SOUZA, E.; OLIVEIRA, R. A. N. A Sala de Aula de Física: Ludicidade e Diálogo. Educação e Fronteiras [On-Line]. Dourados, v. 2, n. 6, p. 37-55, set./dez. 2012.

Tecnologia, Sociedade e Educação na Era Digital [livro eletrônico]/Márcio Luiz Corrêa Vilaça, Elaine Vasquez Ferreira de Araújo (Organizadores). - Duque de Caxias, RJ: UNIGRANRIO, 2016.

TENÓRIO, A.; RODRIGUES, F.O.S.; TENÓRIO, T. Jogos e Simulações Digitais na Prática de Ensino de Professores de Matemática. Revista de Educação, Ciências e Matemática. v. 5, n. 3, p. 103-116. set/dez. 2015.

VYGOTSKY, L. S. A formação social da mente. São Paulo: Martins Fontes, 2007.

ZUIN, V. G.; ZUIN, A. A. S.. O Celular na Escola e o Fim Pedagógico. Educação e Sociedade., Campinas, v. 39, n. 143, p. 419-435, abr.-jun., 2018. 